\title{
Targeted photodynamic therapy treatment of in vitro A375 metastatic melanoma cells
}

\author{
Channay Naidoo', Cherie Ann Kruger ${ }^{1}$ and Heidi Abrahamse ${ }^{1}$ \\ ${ }^{1}$ Laser Research Centre, University of Johannesburg, Johannesburg, South Africa \\ Correspondence to: Cherie Ann Kruger, email: cherier@uj.ac.za \\ Keywords: metastatic melanoma; nano active targeting; zinc phthalocyanine tetra-sulphonic acid; photodynamic therapy \\ Received: July 17, $2019 \quad$ Accepted: August 17, $2019 \quad$ Published: October 22, 2019 \\ Copyright: Naidoo et al. This is an open-access article distributed under the terms of the Creative Commons Attribution License \\ 3.0 (CC BY 3.0), which permits unrestricted use, distribution, and reproduction in any medium, provided the original author and \\ source are credited.
}

\section{ABSTRACT}

Metastatic Melanoma (MM) is a deadly form of skin cancer and many photodynamic therapy (PDT) studies have noted limitations in relation to effective photosensitizer (PS) drug uptake in tumors. The focus of this study was to develop a PS multicomponent nanoparticle drug conjugate carrier system which specifically targets MM cells via biomarkers to actively enhance PS delivery and so improve MM PDT. An antibody-metallated phthalocyanine-polyethylene glycol-gold nanoparticle drug conjugate, was successfully synthesized and characterized. PS active drug targeting PDT experiments at $673 \mathrm{~nm}$ were conducted within in vitro cultured MM. Results noted that this drug conjugate enhanced the PDT treatment of MM, through improved subcellular localization of the PS, as well as noted significantly improved cytotoxic and late apoptotic cellular death in cells. The results from this study demonstrate that through the bio-active antibody PS drug targeting of $M M$, the efficacy of PDT treatment for this cancer can be enhanced.

\section{INTRODUCTION}

Melanoma represents about $10 \%$ of all skin malignancies, however due to its ability to metastasize and spread, it accounts for more than $80 \%$ of all skin cancer related deaths, with approximately 100000 fatalities annually $[1,2]$. There are currently various cancer treatments available for melanoma such as chemotherapy, surgery, biological therapy and radiotherapy or immunotherapy, however, these treatments are sometimes invasive and induce harsh unwanted side effects. Therefore, investigation into unconventional forms of treatment for melanoma such as PDT administered alone or in combination with other therapies need to be conducted to reduce the side effects and be non-invasive [3]. In relation to immunotherapy the standard of care of MM patients, include immunomodulating modalities such as anti-PD-1 drugs (nivolumab, pembrolizumab) and anti-CTLA-4 antibody ipilimumab which have provided "proof of concept" for further research in the field of immunooncology, however to date this treatment option still remains unavailable [4].
PDT involves the administration of a light sensitive non-toxic drug known as a PS which passively localizes in tumor cells $[3,5]$ When this PS is irradiated with visible red light (620 - $690 \mathrm{~nm})$, it becomes excited and so forms cytotoxic reactive oxygen species (ROS) $[3,5]$. ROS accomplishes photo-cytotoxicity by promoting cellular oxidative stress, which induces cell death and so causes tumor destruction [5].

PDT is a feasible treatment modality for cancer, however, in relation to MM various studies have noted some PS drawbacks [2, 3]. Since conventional PS drugs can only passively diffuse into tumor cells, it has been noted that sometimes they are absorbed by healthy tissues, causing undesirable side effects and tend to be absorbed in lowered concentrations than originally administered [6]. Additionally, PSs are recognized as foreign matter by biological barriers and so in vivo tend to be destroyed by immune system barriers, resulting in a poor drug uptake [7]. Moreover, solid melanoma tumors are seemly more resistant to PDT, due to poor absorption of PS drugs and limitations of laser light being able to reach these cells [3]. Literature has noted positive PDT treatments of MM 
with zinc sulpho phthalocyanine $\left(\mathrm{ZnPcS}_{\text {mix }}\right) \mathrm{PSs}$, due to their longer light wavelength absorption peaks above 650 $\mathrm{nm}$, being able to penetrate deep seated tumors, rich in melanin, however noted that $\mathrm{ZnPcS}$ tends to aggregate, due to their poor water solubility and sulpho purity, so this limited their overall PDT effectivity [8].

Numerous studies have reported that gold nanoparticles (AuNPs) can be utilized as drug carriers in PDT applications to improve PS passive uptake in tumor cells, due to their abilities to avoid biological barriers, ease of functionalization, as well as abilities to promote photothermal cell death induction due to their metallated content.[9-12] Additionally, studies have noted that Melanoma Inhibitory Activity (MIA) is an antigen, which is specially overexpressed on melanoma cells only, thus making it a highly specific and sensitive biomarker for MM drug uptake targeting [13]. Thus, the conjugation of a MM tumor-targeting antibody (Ab) such as Anti-MIA, onto a sulpho pure ZnPcS PS carrying AuNPs surface would seem highly desirable, in order to promote drug solubility, as well as active MM tumor targeting uptake in order to enhance PDT seems promising [14-16]. Furthermore, studies have reported that Zinc phthalocyanine tetra-sulphonic acid $\left(\mathrm{ZnPcS}_{4}\right)$ is more soluble than $\mathrm{ZnPcS}_{\text {mix }}$, due to its tetra sulphonated groups [8]. Additionally, studies have determined the threshold for acute toxicosis of parenterally administered $\mathrm{ZnPcS}_{4}$, in mice and evaluated the compound's safety in a phase I clinical trial of $\mathrm{ZnPcS}_{4}$ based PDT in pet dogs with naturally occurring tumors. These animal studies confirmed the good tolerability and systemic safety of $\mathrm{ZnPcS}_{4}$, as no changes in immunological, behavioral and organic parameters could be detected upon treatment with the non-photoactivated $\mathrm{ZnPcS}_{4}$ and so show the extraordinary photoactive potential of the $\mathrm{ZnPcS}_{4}$ as a photosensitizer for PDT [17-20].

Thus, this study $\mathrm{ZnPcS}_{4}$ PS drug was conjugated onto the surface of amine functionalized AuNPs, which had Anti-MIA antibodies bound to its surface in order to actively improve PS drug delivery and increase its uptake and absorption within MM target tumor cells. The outcome of this study clearly enhanced PDT treatment for this type of skin cancer (Figure 1) [17, 18].

\section{RESULTS}

\section{Molecular characterization of the final PS drug conjugate}

\section{UV-Visible spectroscopy}

The absorption spectra of the final PS drug conjugate were read using the spectrum/purity scan mode within the 400-800 $\mathrm{nm}$ spectral region (Figure 2). $500 \mu \mathrm{M}$ of $\mathrm{ZnPcS}_{4}$ noted two major $\mathrm{Q}$ bands of emission
(634 and $674 \mathrm{~nm}$ ) within the far-red spectral range and AuNP-PEG5000-CSH-NH ${ }_{2}$ noted a peak absorption band of $520 \mathrm{~nm}$, which equates to $2.85 \times 10^{15}$ particles/ml [21]. When both of these absorption spectra were compared to the final PS drug conjugate, both absorption peaks still remained prominent, however lowered in absorption, confirming that $\mathrm{ZnPcS}_{4}$ had been successfully bound to AuNP-PEG5000-SH-NH ${ }_{2}$, and the PS ROS integrity, as well as AuNP photothermal properties had remained intact. When comparing the major absorption peak fold falls of the PS drug conjugate to $\mathrm{ZnPcS}_{4}$ and AuNPPEG5000-SH-NH $\mathrm{N}_{2}$ controls, it was determined that 0.89 $\times 10^{15}$ AuNP-PEG5000-SH-NH 2 particles/ml had been successfully bound to $227 \mu \mathrm{M}$ of $\mathrm{ZnPcS}_{4}$ PS drug. Since, the major absorption peaks of the final PS drug conjugate at 520 and $673 \mathrm{~nm}$ in relation to $\mathrm{ZNPcS}_{4}$ and AuNP control peaks did not broaden much, this suggests the final PS drug conjugate had good size distribution with minimal aggregation [22]. However, since the absorption peaks of the final PS drug conjugate did slightly broaden; this is indicative of definitive bonding between all the chemical components, as there is an obvious increase in molecular size [23]. Moreover, the slight shift in the resonance peak position of AuNP at $520 \mathrm{~nm}$, within the final molecular conjugate was also indicative that $\mathrm{ZnPcS}_{4}$ and Anti-MIA $\mathrm{Ab}$ had successfully bound to its surface [23]. Finally, over 8 weeks of the experimental assays the absorption spectra Q bands of 520, 634 and $674 \mathrm{~nm}$ stayed consistent, suggesting the final PS drug conjugate remained photostable and retained its photothermal properties after molecular synthesis and overtime (Figure 3).

With reference to Figure 4, the protein direct UV $280 \mathrm{~nm}$ spectral region of the final PS drug conjugate noted a 5.8 absorbance fold fall when compared to control $200 \mu \mathrm{g} / \mathrm{ml}$ Anti-MIA Ab within the same spectral range. This finding suggests that only $34 \mu \mathrm{g} / \mathrm{ml}$ of Anti-MIA Ab was successfully bound to the final molecular PS drug conjugate. According to literature, amine $\left(\mathrm{NH}_{2}\right)$ functional groups produce a high absorption peak at a wavelength spectrum of $195 \mathrm{~nm}$, whereas the condensation of an amine with a carboxylic acid to produce an amide peptide bond (CO-NH) tend to produce a high absorption peak at a wavelength spectra of $220 \mathrm{~nm}$ [24]. The AuNP-PEG5000$\mathrm{SH}-\mathrm{NH}_{2}$ control noted a high $\mathrm{NH}_{2}$ group absorption peak at a wavelength spectrum of $195 \mathrm{~nm}$, which is expected since it was $\mathrm{NH}_{2}$ functionalized. Additionally, the AntiMIA Ab control also noted a high $\mathrm{NH}_{2}$ group absorption peak at $195 \mathrm{~nm}$, which is predictable considering its n' terminal has $\mathrm{NH}_{2}$ functional groups. Whereas, the final PS drug conjugate noted lowered $\mathrm{NH}_{2}$ group absorption peak at $195 \mathrm{~nm}$, when compared to that of the AuNP control, suggesting that $\mathrm{NH}_{2}$ group on the AuNP had condensed with the activated carboxylic group on the activated c' terminus of the Abs to produce a CO-NH bond. The final $\mathrm{CO}-\mathrm{NH}$ bond was additionally confirmed, by observing the high $220 \mathrm{~nm}$ absorption peak within the final PS 


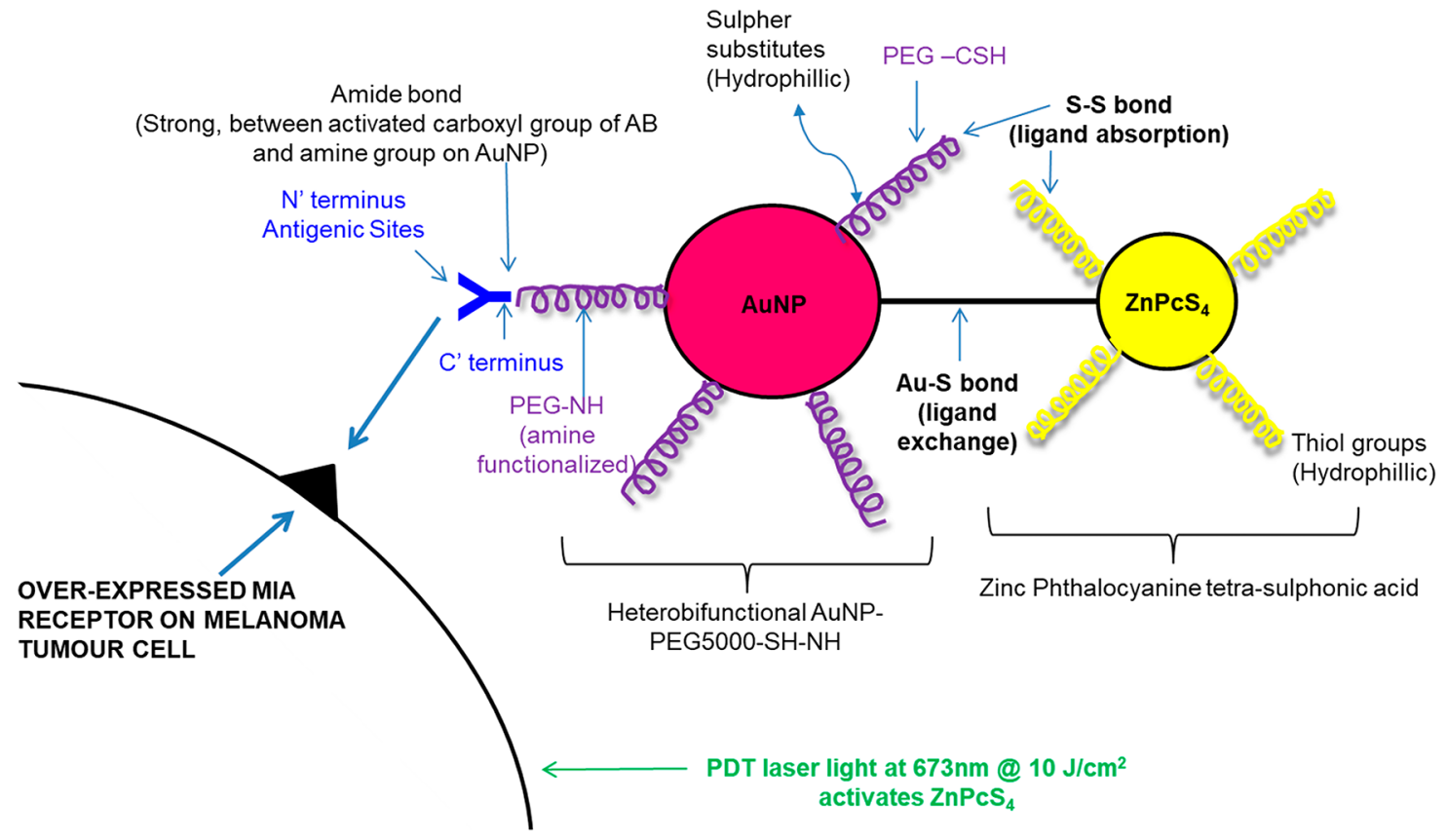

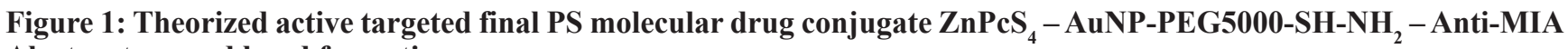
Ab structure and bond formation.

drug conjugates spectra. Moreover, since the final PS drug conjugate still noted the presence of $\mathrm{NH}_{2}$ functional groups at the $195 \mathrm{~nm}$ absorption peak, this suggested that the n' terminus active targeting sites of the Anti-
MIA Ab within the final multicomponent active nano PS molecular drug conjugate remained unaffected, correctly orientated (i. e. bound to the AuNP-PEG5000-SH-NH $\mathrm{N}_{2}$ at $c$ ' terminus) and so were considered functional for active

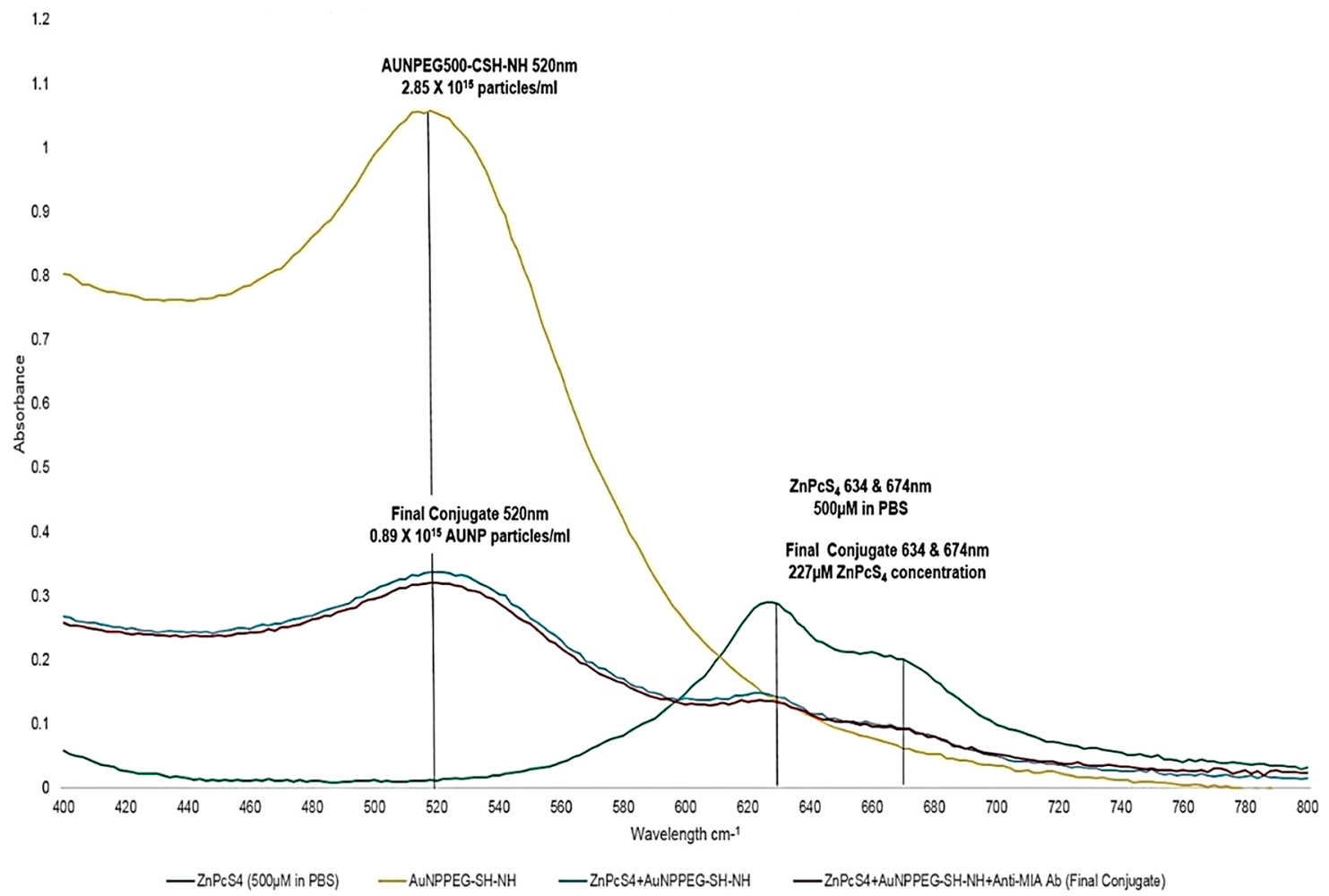

Figure 2: UV-Visible absorption spectra of the final molecular PS drug conjugate $\left(\mathrm{ZnPcS}_{4}-\mathrm{AuNP}-\mathrm{PEG5000-SH- \textrm {NH } _ { 2 }}\right.$ - Anti-MIA Ab) and various controls within the 400 to $800 \mathrm{~nm}$ spectral region. 


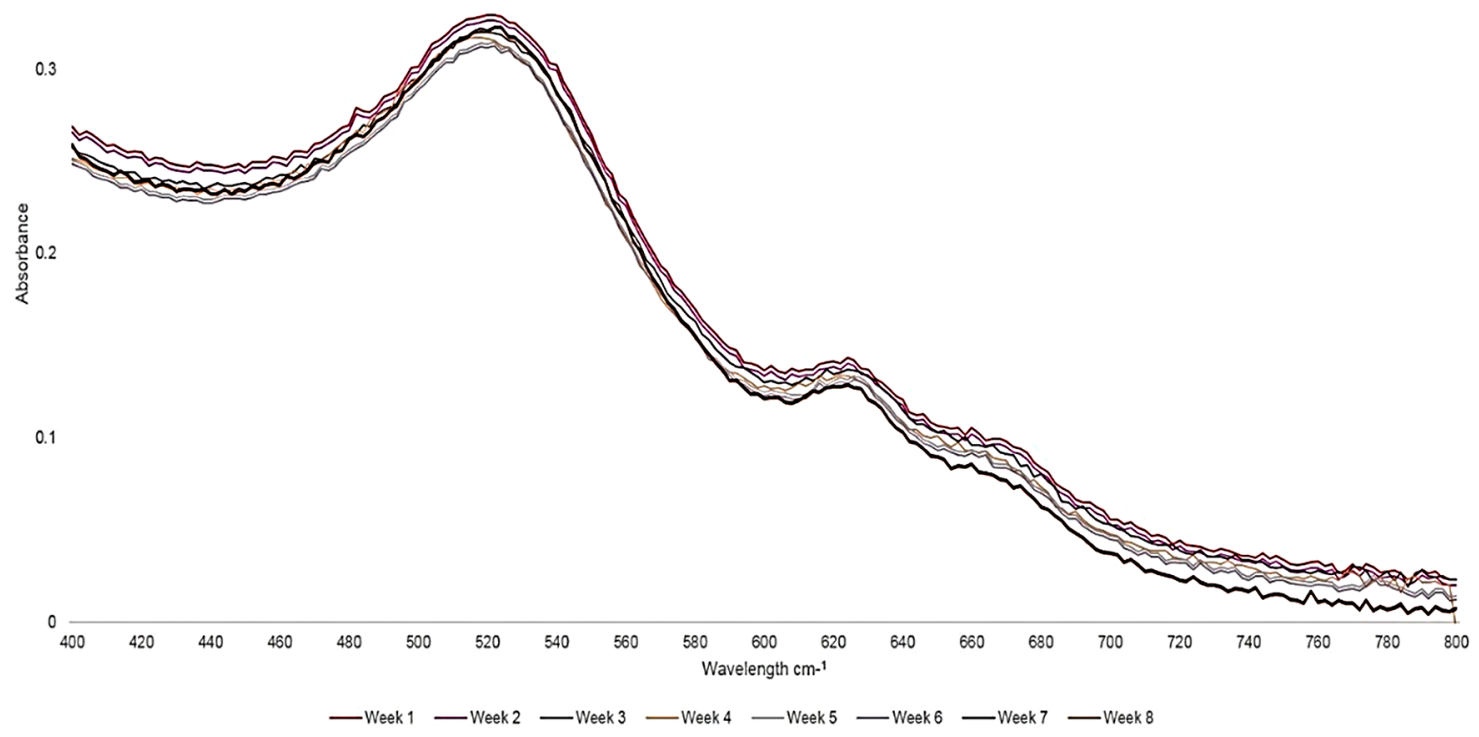

Figure 3: UV-Visible absorption and fluorescent photostability spectra of the final molecular PS drug conjugate $\left(\mathrm{ZnPcS}_{4}\right.$-AuNP-PEG5000-SH-NH - Anti-MIA Ab) recorded within the 400 to $800 \mathrm{~nm}$ spectral region over an 8-week period.

PS drug delivery. Lastly, the final PS drug conjugate had a higher absorption spectra within the 250 to 280 $\mathrm{nm}$ range than when compared to AuNP and $\mathrm{ZnPcS}_{4}$ controls, suggesting possible ligand absorption between the sulphonated $\mathrm{ZnPcS}_{4}$ PS and AuNP-PEG5000-SH-NH had occurred in order to create di-sulphide bond [25].

\section{FT-IR spectroscopy}

FT-IR spectroscopy has various applications in structural identification, and can be used for qualitative analysis of molecular ligand and absorption bond formations, as well as peptide bond identification within the final PS drug conjugate (Figure 5) [26-29]. FT-IR

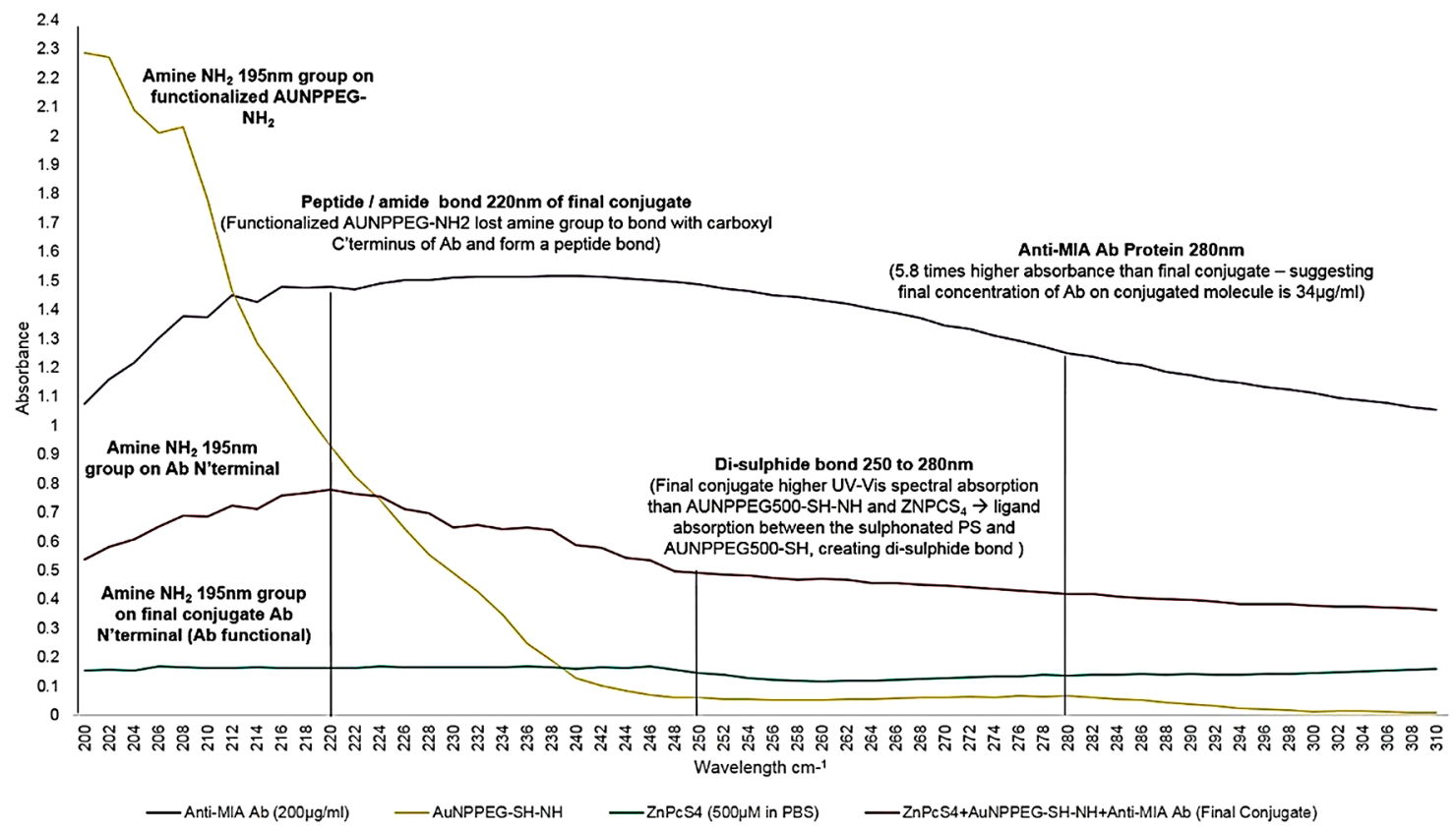

Figure 4: UV-Visible protein direct absorption spectra of the PS drug conjugate and various controls within the 200 to $310 \mathrm{~nm}$ spectral region. 


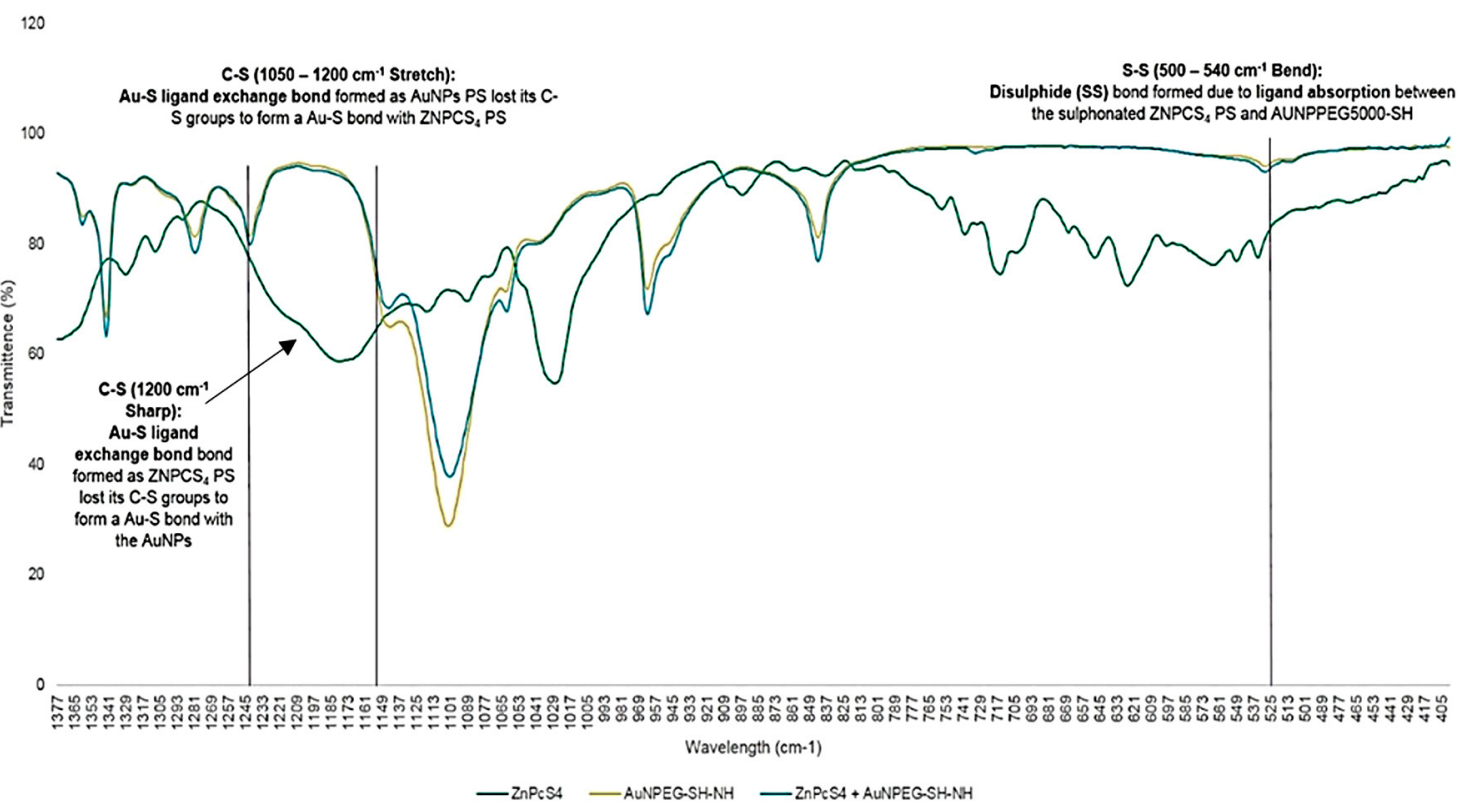

Figure 5: FT-IR spectra analysis for confirmatory ligand exchange (Au-S) and absorption (S-S) bond confirmation between AuNP-PEG5000-SH-NH 2 and $\mathrm{ZnPcS}_{4}$ within the final PS drug conjugate.

characterization results revealed the presence of $\mathrm{Au}-\mathrm{S}$ ligand exchange bonding, since the spectra of control conjugate $\mathrm{ZnPcS}_{4}$ - AuNP-PEG5000-SH-NH ${ }_{2}$, noted a C-S (1050-1200 $\left.\mathrm{cm}^{-1}\right)$ stretch shift, suggesting AuNPPEG5000-SH-NH $\mathrm{H}_{2}$ lost their C-S groups to bond with $\mathrm{ZnPcS}_{4}[26,27]$. Moreover, the presence of Au-S ligand exchange bonding was confirmed since the FT-IR spectra of $\mathrm{ZnPcS}_{4}$ - AuNP-PEG5000-SH-NH $\mathrm{N}_{2}$ noted a loss of a C-S $\left(1200 \mathrm{~cm}^{-1}\right)$ sharp band when compared to $\mathrm{ZnPcS}_{4}$ alone, suggesting $\mathrm{ZnPcS}_{4}$ lost its C-S groups to bond with AuNP-PEG5000-SH-NH ${ }_{2}$ [28]. Finally, the FT-IR spectra of $\mathrm{ZnPcS}_{4}$ - AuNP-PEG5000-SH-NH ${ }_{2}$ noted a sharp S-S $\left(500-540 \mathrm{~cm}^{-1}\right)$ bend suggesting that ligand absorption between the sulphonated $\mathrm{ZnPcS}_{4}$ PS and AuNP-PEG5000SH-NH ${ }_{2}$ occurred to form a weak di-sulphide bond [29].

Furthermore, the final molecular conjugate $\left(\mathrm{ZnPcS}_{4}\right.$ - AuNP-PEG5000-SH-NH 2 - Anti-MIA Ab) was also subjected to FT-IR analysis for confirmatory amide bond analysis, by noting and identifying the formation of amide bonds when compared to the FT-IR spectra of AuNPPEG5000-SH-NH ${ }_{2}$ alone (Figure 6). With referral to Figure 6 , FT-IR characterization revealed that final molecular conjugate noted a $\mathrm{C}=\mathrm{O}\left(1680-1630 \mathrm{~cm}^{-1}\right)$ stretch and sharp $\mathrm{N}=\mathrm{H}$ bend $\left(1640-1650 \mathrm{~cm}^{-1}\right)$, when compared to the AuNPPEG5000-SH-NH $\mathrm{N}_{2}$ alone, suggesting that strong primary and secondary amide peptide bonds (CO-NH) formed between the amine $\left(\mathrm{NH}_{2}\right)$ functionalized group on the AuNPs and the activated c' terminus of the Anti-MIA Ab [29].

\section{Dynamic light scattering and zeta potential}

DLS and ZP results are shown in Table 1 and Figure 7. The DLS hydrodynamic radius distribution of the final PS drug conjugate noted a single narrow width peak, indicating it remained spherical with no aggregation and was homogenously pure. The final PS drug conjugate reported a mean Z-average diameter of $45.20 \pm 6.458 \mathrm{~nm}$, suggesting it was indeed small enough to be considered as an active nanodrug carrying system [30]. The final PS conjugate reported a PDI purity value of 0.306 , signifying it was monodisperse and mostly consisted of single sized particles. The ZP value of the final PS drug conjugate was found to be $28.6 \pm 3.73 \mathrm{mV}$, proposing that it was moderately stable with a slightly positively charge, hinting at the fact that it should remain stable within an in vivo environment, as well as be passively be taken up and retained within tumorous cells more selectively $[30,31]$.

\section{Subcellular localization}

Immunofluorescent studies noted a far more predominant localization of $\mathrm{ZnPcS}_{4}$ PS (red) in the cytoplasm (green) and nuclei (blue) of MM cells, which received the final PS drug conjugate, than when compared control PS drug administration alone (Figure 8). These findings suggest that the targeting affinity of the PS drug conjugate in relation to Anti-MIA Ab biomarker specify for MM cells was functional, and so improved the subcellular localization and concentration uptake within these cells.

\section{$\mathrm{ZnPcS}_{4}$ PS PDT dose response assay}

In order to establish the $\mathrm{IC}_{50}$ of the $\mathrm{ZnPcS}_{4} \mathrm{PS}$, various concentrations of $\mathrm{ZnPcS}_{4} \mathrm{PS}$ and/or PDT laser irradiation (at a wavelength of $673 \mathrm{~nm}$ using a fluency of $10 \mathrm{~J} / \mathrm{cm}^{2}$ ) were applied to MM cells and results were reported in the form of Trypan Blue Exclusion cell 


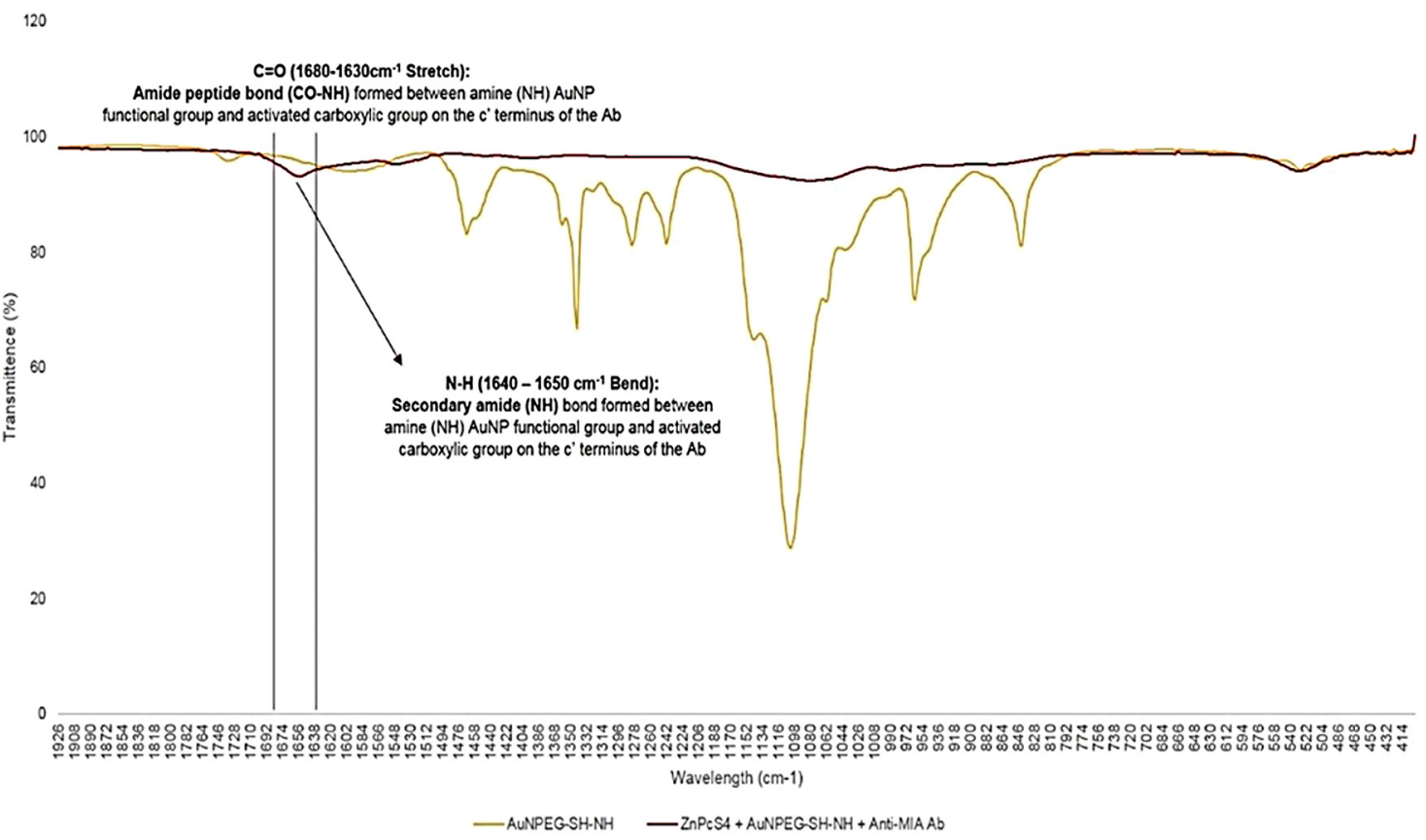

Figure 6: FT-IR spectra analysis for confirmatory amide (CO-NH) bond confirmation between AuNP-PEG5000-SH$\mathrm{NH}_{2}$ and the activated carboxylic group on the c' terminus of the Anti-MIA Ab within the final PS drug conjugate.

viability tests (Figure 9) and Lactate Dehydrogenase (LDH) cytotoxicity and membrane integrity assay results (Figure 10).

The Trypan Blue Exclusion cell viability test (Figure 9) noted control MM cells, which received various concentrations of $\mathrm{ZnPcS}_{4}$, with no laser irradiation applied to them, that there was an insignificant dose dependent decrease in cell viability. This suggested that the $\mathrm{ZnPcS}_{4}$ in its inactivated form, when administered alone lacks dark toxicity. Additionally, control MM cells which received laser irradiation alone, also noted no cellular damage. Experimental groups of MM cells which received 0.25 and $0.5 \mu \mathrm{M}$ of $\mathrm{ZnPcS}_{4}$ and laser irradiation, showed no significant decreases in cell viability. However, cells which received 1, 2.5, 5 and $10 \mu \mathrm{M}$ of $\mathrm{ZnPcS}_{4}$ with laser irradiation showed dose dependent significant decreases in cell viability, when compared to the cells only control. The LDH cytotoxicity and membrane integrity assay (Figure 10) reported similar significant results within experimental groups which received 1, 2.5, 5 and $10 \mu \mathrm{M}$ of $\mathrm{ZnPcS}_{4}$ with laser irradiation, while all control groups noted insignificant findings.

These results indicate that $\mathrm{ZnPcS}_{4}$ is an excellent PS for the use of PDT on MM, since it is capable of

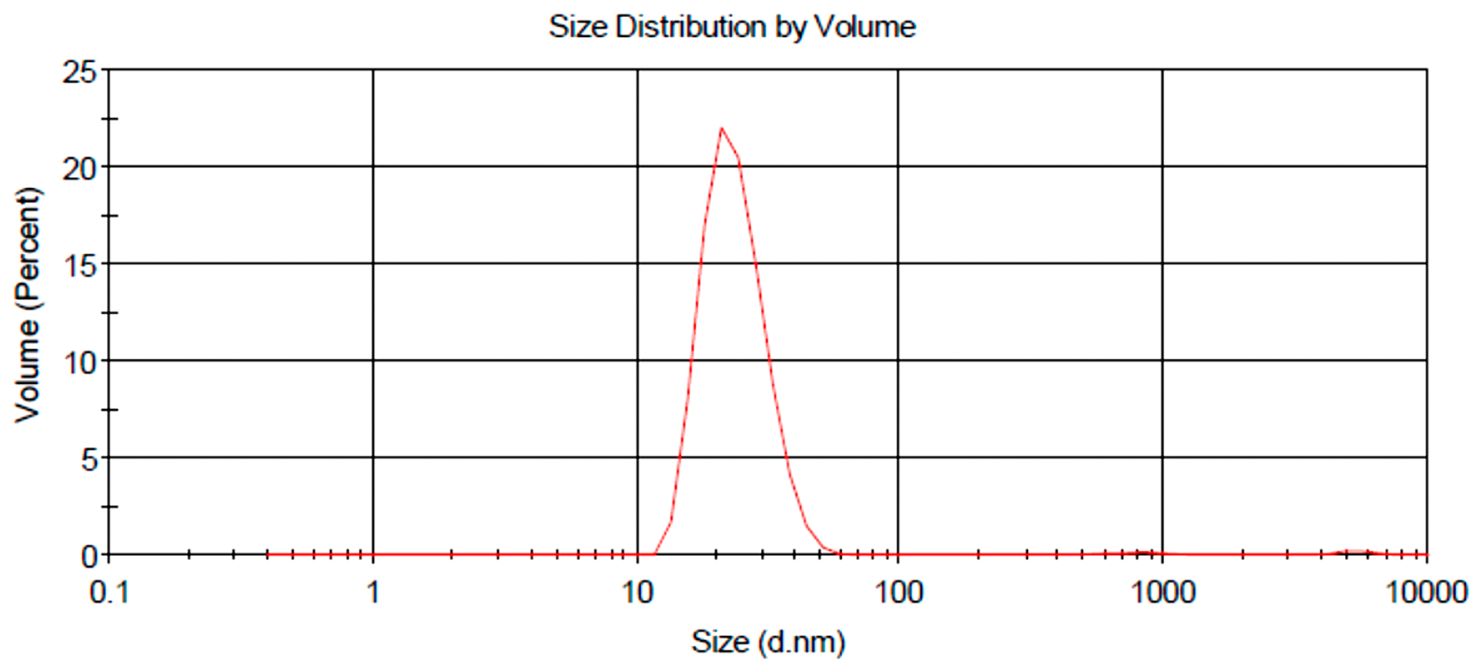

Figure 7: DLS hydrodynamic radius distribution graph of final molecular drug conjugate consisting of $\mathrm{ZnPcS}_{4}$ AuNP-PEG5000-SH-NH 2 - Anti-MIA Ab. 
Table 1: DLS and ZP results for characterization of final molecular NP PS drug delivery system

\begin{tabular}{|c|c|c|c|}
\hline Sample & $\begin{array}{c}\text { Mean Z-Average Diameter } \\
\text { Measured by DLS (nm) }\end{array}$ & Polydisersity Index (PDI) & Zeta Potential (mV) \\
\hline AuNP & $11.06 \pm 1.02$ & 0.247 (Monodisperse) & \\
\hline $\mathrm{ZnPcS}_{4}$ & $15.44 \pm 2.23$ & 0.406 (Monodisperse) & \\
\hline $\begin{array}{c}\text { Expected average } \mathrm{ZnPcS}_{4}- \\
\text { AuNP }\end{array}$ & $41.94 \pm 1.63$ & & \\
\hline $\begin{array}{c}\text { Result average } \mathrm{ZnPcS}_{4}- \\
\text { AuNP }\end{array}$ & $42.94 \pm 3.625$ & 0.289 (Monodisperse) & \\
\hline Anti-MIA Ab & $3.21 \pm 1.83$ & 0.352 (Monodisperse) & \\
\hline $\begin{array}{c}\text { Expected average } \mathrm{ZnPcS}_{4}- \\
\text { AuNP - Anti-MIA Ab }\end{array}$ & $49.36 \pm 2.73$ & & \\
\hline $\begin{array}{l}\text { Result average } \mathrm{ZnPcS}_{4}- \\
\text { AuNP - Anti-MIA Ab (final } \\
\text { molecular drug conjugate) }\end{array}$ & $45.20 \pm 6.458$ & 0.306 (Monodisperse) & $\begin{array}{c}28.6 \pm 3.73 \text { (Moderately } \\
\text { stable) }\end{array}$ \\
\hline
\end{tabular}

substantial cell death induction. However, in order to establish if the PS when administered in a drug carrying conjugate, was capable of targeted and improved PDT, the $\mathrm{IC}_{50}$ of $2.5 \mu \mathrm{M} \mathrm{ZnPcS}$ PS with laser irradiation applied was chosen, as it reported a significant decrease of $38 \% * *$ in cell viability and $48 \% * *$ cellular cytotoxicity. Thus, in relation to the below final conjugate studies: the concentration of the final PS drug

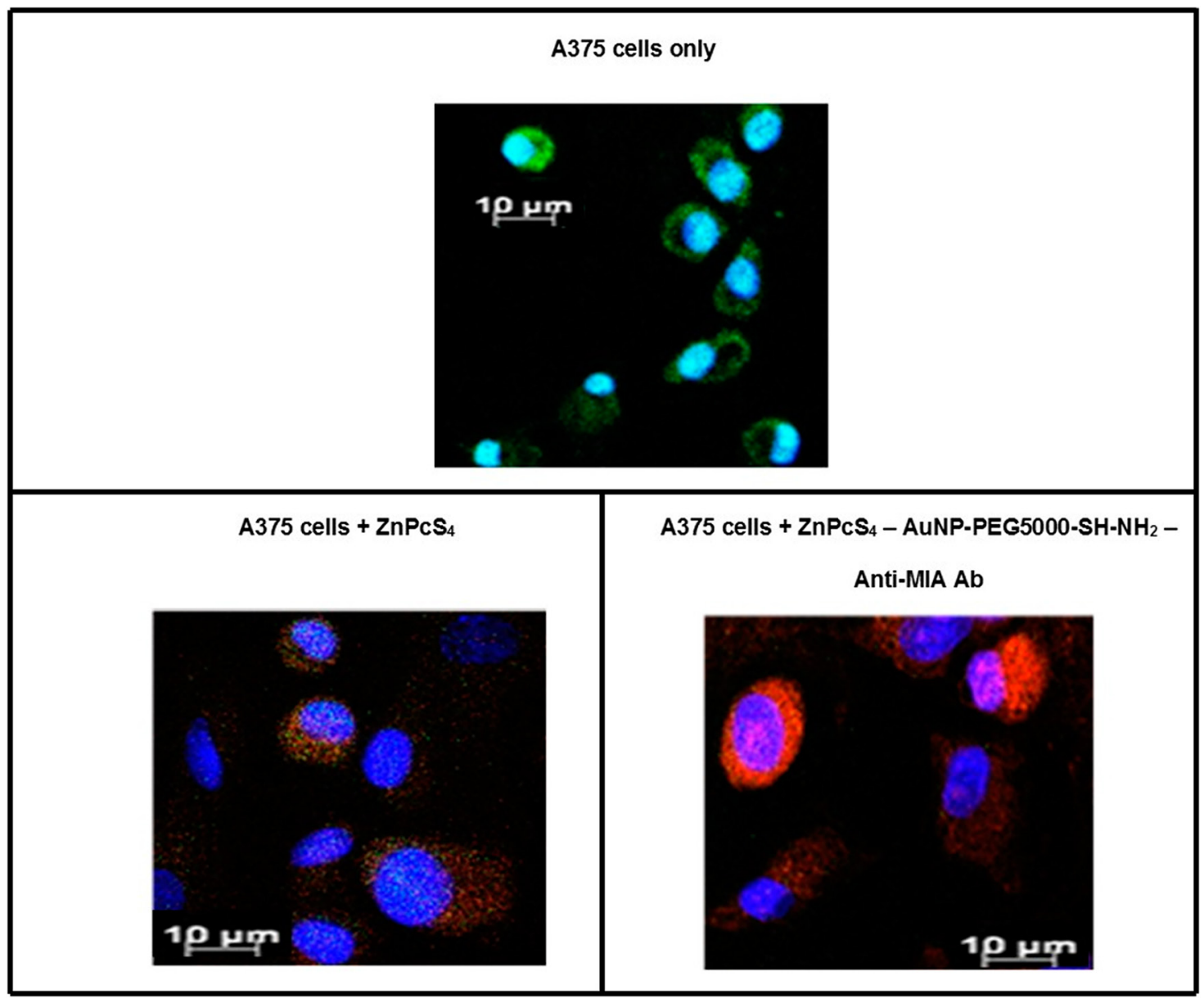

Figure 8: Subcellular localization results of $\mathrm{ZnPcS}_{4} \mathrm{PS}$ alone verses $\mathrm{PS}$ drug conjugate within in vitro cultured MM cells. $\left(\right.$ Blue $=$ nuclei, green $=$ membrane proteins and $\mathrm{red}=$ localization of $\mathrm{ZnPcS}_{4} \mathrm{PS}$ drug $)$. 


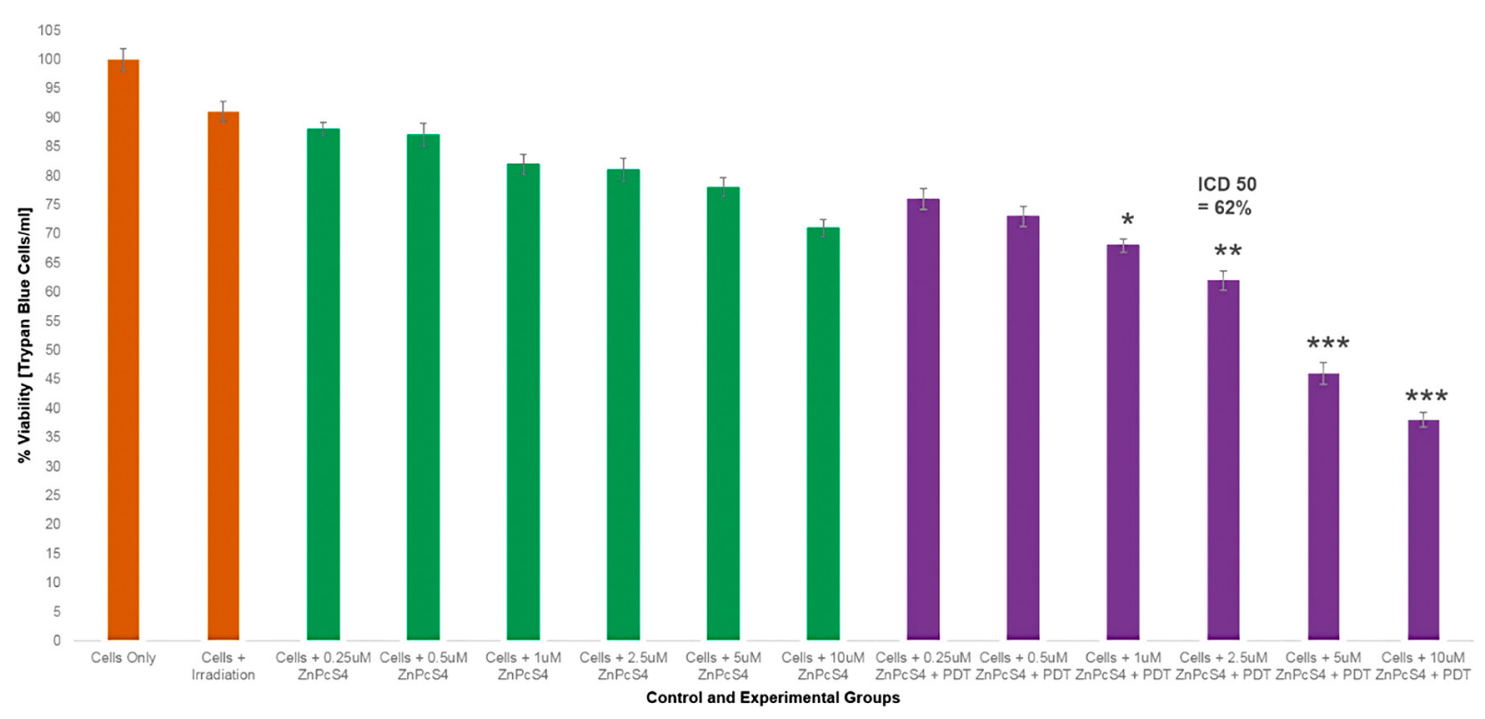

Figure 9: Trypan blue exclusion cell viability results of control and experimental groups of $\mathrm{ZnPcS}_{4}$ at various concentrations with and without laser irradiation at $673 \mathrm{~nm}$ at $10 \mathrm{~J} / \mathrm{cm}^{2}$

conjugate that was administered to cells consisted of $2.5 \mu \mathrm{M} \mathrm{ZnPcS}_{4}$ PS, bound to $0.425 \mu \mathrm{g} / \mathrm{ml}$ Anti-MIA Ab with $1.11 \times 10^{13}$ AuNP-PEG5000-SH-NH 2 particles $/ \mathrm{ml}$ in $0.001 \mathrm{M}$ PBS.

\section{$\mathrm{ZnPcS}_{4}$ - AuNP-PEG5000-SH-NH2 - Anti- MIA ab final PS drug conjugate PDT response assays}

\section{Morphological assessment}

Changes in cellular morphology of various control group and PDT experimental groups, were assessed 24 hours post irradiation by light microscopy by comparing these images to the MM cells only control (Figure 11). No significant morphological damage was noted in the cells control group which received laser treatment only, suggesting laser treatment alone doesn't induce phototoxicity. Control cell groups which received 2.5 $\mu \mathrm{M} \mathrm{ZnPcS}{ }_{4}-$ AuNP-PEG5000-SH-NH ${ }_{2}$ or $2.5 \mu \mathrm{M}$ final PS drug conjugate only, no significant change in cellular morphology was observed, signifying that the final molecular drug conjugate exhibited no dark toxicity.

Within the PDT treated control groups, which received with $2.5 \mu \mathrm{M} \mathrm{ZnPcS}$ - AuNP-PEG5000-SH$\mathrm{NH}_{2}$, changes in morphological structure, such as loss of cellular shape, detachment and free-floating cells was observed. These results are supported by studies by Conde

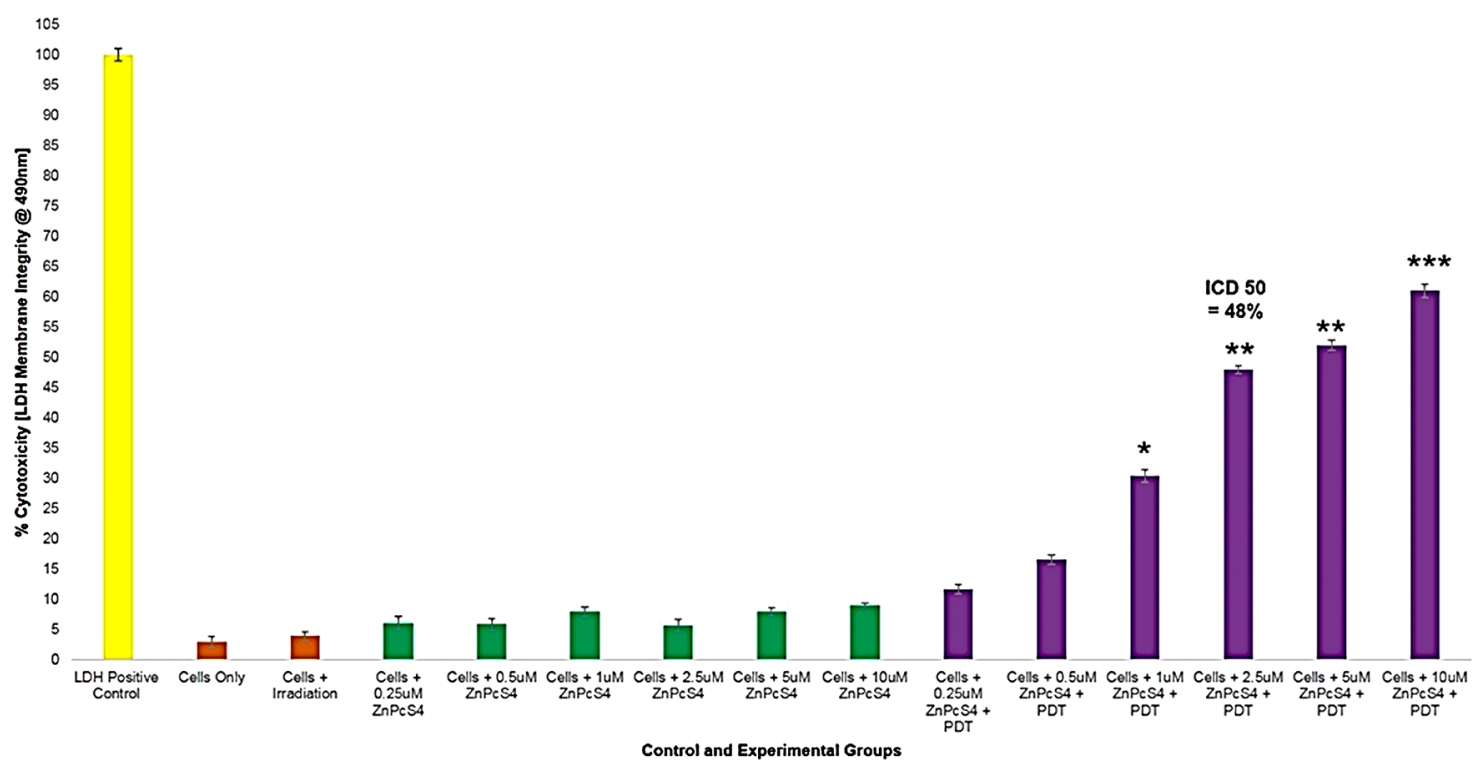

Figure 10: $\mathrm{LDH}$ cellular cytotoxicity assay results of control and experimental groups of $\mathrm{ZnPcS}_{4}$ at various concentrations with and without laser irradiation at $673 \mathrm{~nm}$ at $10 \mathrm{~J} / \mathrm{cm}^{2}$. 


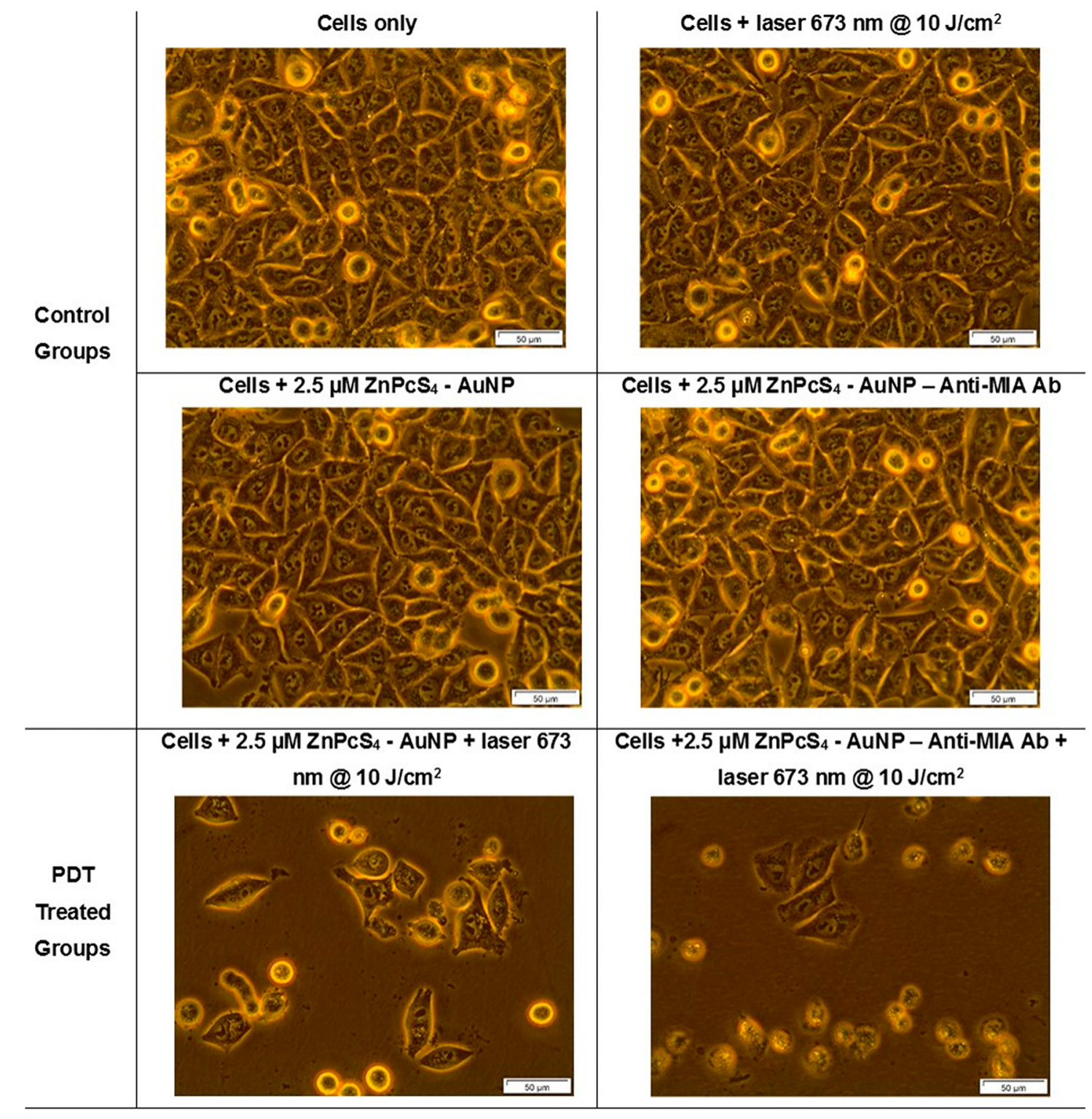

Figure 11: Light microscopy morphological images of MM cells at 400 $\times$ magnification of control and experimental groups that were subjected to laser irradiation at a wavelength of $673 \mathrm{~nm}$ and a fluence of $10 \mathrm{~J} / \mathrm{cm}^{2}$ during final PS drug conjugate PDT response assays.

et al. (2012) whom noted that within PDT applications AuNPs have laser light induced photothermal properties, which assist in tumor destruction [12]. However, the most significant cellular damage was noted within the PDT treated experimental group, which received 2.5 $\mu \mathrm{M}$ of the final PS drug conjugate, as cells appeared to be completely detached, rounded up and cellular debris was seen. These findings suggest that the final PS drug conjugate Anti-MIA Ab actively enhanced cellular uptake of the $\mathrm{ZnPcS}_{4}$ and so enhanced the PDT treatment outcome. These findings correlate with studies by Hong et al. (2016), which highlight that NP PS drug uptake and absorption can be improved, when NPs are functionalized with targeting biomolecules, which allow for active and specific targeted delivery in tumor cells and so enhance PS cellular localization and overall PDT outcome [32].

\section{Trypan blue exclusion test}

In order to determine the effect, the final PS drug conjugate had during PDT response assays, various control and experimental groups were subjected to Trypan blue exclusion staining (Figure 12). The MM cells only control group noted $98 \%$ viable cells and so this was used as reference-base line to statistically compare other results against. Control groups which received laser irradiation only, no substantial decrease in viability was found, suggesting laser irradiation alone, had no effect on cellular viability. Similarly, control cells which received $2.5 \mu \mathrm{M}$ 


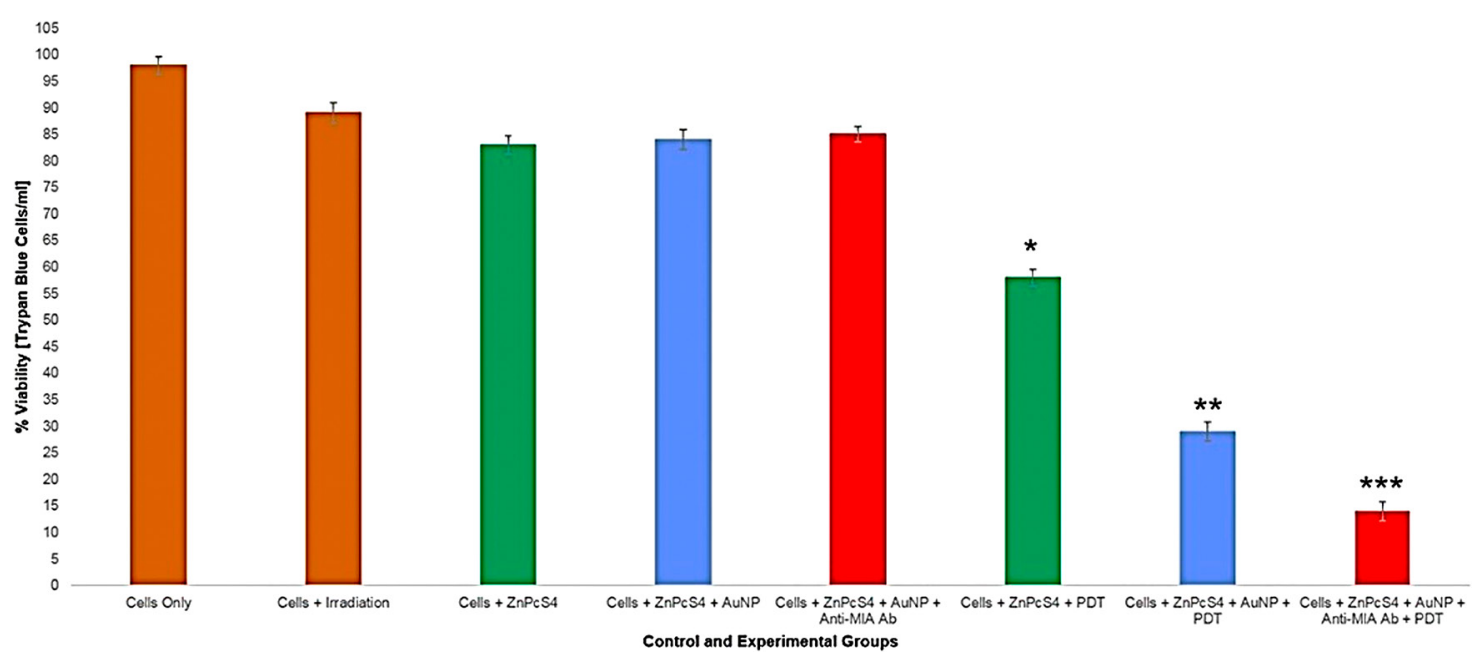

Figure 12: Trypan blue exclusion MM cell viability results of control and experimental groups that were subjected to final PS drug conjugate PDT response assays.

$\mathrm{ZnPcS}_{4}$ only, noted no significant decrease in cell viability, suggesting that this PS drug when administered at this concentration, lacks dark toxicity in cells. Additionally, there was no significant viability decrease observed in cell control groups which received control $2.5 \mu \mathrm{M} \mathrm{ZnPcS}_{4}$ - AuNP-PEG5000-SH-NH ${ }_{2}$ or $2.5 \mu \mathrm{M}$ final PS drug conjugate administration alone. These findings indicate that even when the $\mathrm{ZnPcS}_{4}$ was bound to either AuNP-

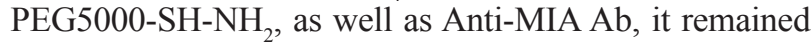
stable (in its inactive form) and so lacked dark toxicity.

The PDT treated groups, which consisted of cells with the addition of either $2.5 \mu \mathrm{M} \mathrm{ZnPcS}_{4}, 2.5 \mu \mathrm{M} \mathrm{ZnPcS}_{4}$ - AuNP-PEG5000-SH-NH ${ }_{2}$ or $2.5 \mu \mathrm{M}$ final PS drug conjugate showed varying significant decreases in cell viability. The PDT treated control group which received 2.5 $\mu \mathrm{M} \mathrm{ZnPcS}_{4}$ with laser irradiation noted a $46 \% *$ decrease in cell viability, whereas the PDT treated control group which received $2.5 \mu \mathrm{M} \mathrm{ZnPcS}_{4}$ - AuNP-PEG5000-SH-NH ${ }_{2}$ with laser irradiation noted an even more significant decrease of $69 \% * *$ in cell viability. These findings are indicative that the bound AuNPs to the PS promoted PDT photothermal induced cellular damage, than when compared to PS drug administration alone [32]. However, the most significant decrease of $84 \% * * *$ in cellular viability, was noted in PDT treated experimental group which received $2.5 \mu \mathrm{M}$ final PS drug conjugate. These findings suggest that the AntiMIA Ab, which was conjugated to the final PS drug carrier, actively enhanced PS drug uptake in cells and so improved PDT treatment outcomes immensely.

\section{LDH cellular cytotoxicity and membrane integrity assay}

In order to determine the cytotoxic effect, the final PS drug conjugate had during PDT response assays, various control and experimental groups were subjected to LDH membrane damage integrity analysis (Figure 13). The MM cells only control group noted negligible cytotoxicity and so this was used as reference-base line to statistically compare other results against. Control groups which received laser irradiation or $2.5 \mu \mathrm{M} \mathrm{ZnPcS}_{4}$ only, no substantial increase in cellular cytotoxicity was found, suggesting that laser treatment alone or PS addition pre-PDT has significant impact on cellular cytotoxicity. Additionally, there was no significant cytotoxicity increase observed in cell control groups, which received control 2.5 $\mu \mathrm{M} \mathrm{ZnPcS}_{4}-$ AuNP-PEG5000-SH-NH $_{2}$ or $2.5 \mu \mathrm{M}$ final PS drug conjugate administration alone. These findings indicate that when the $\mathrm{ZnPcS}_{4}$ was bound to either AuNPPEG5000-SH-NH ${ }_{2}$, and /or Anti-MIA Ab, pre-PDT it remained stable and had no cytotoxic effects on cells.

All PDT treated groups reported highly significant cellular cytotoxicity values which varied over the different groups. Within PDT treated control groups which received $2.5 \mu \mathrm{M} \mathrm{ZnPcS}$ PS drug only, a significant increase of $45 \% * * *$ cellular cytotoxicity was noted. However, within PDT treated control groups which received 2.5 $\mu \mathrm{M} \mathrm{ZnPcS}{ }_{4}-$ AuNP-PEG5000-SH-NH ${ }_{2}$, a significantly higher increase of $59 \% * * *$ was found. These findings are supportive of previous results, whereby it has been stated that the binding of AuNPs to PSs stimulate PDT induced photothermal activities, which in turn are cytotoxic to cells $[32,33]$. However, the most significant cellular cytotoxicity of $73 \% * * *$ was noted in PDT treated experimental groups, which received $2.5 \mu \mathrm{M}$ final PS drug conjugate administration. These findings suggest that the conjugation of Anti-MIA Ab to $\mathrm{ZnPcS}_{4}-\mathrm{AuNP}-$ PEG5000-SH-NH ${ }_{2}$, actively enhanced PS uptake in MM cells and so improved cellular cytotoxicity post-PDT treatment outcomes significantly.

\section{Flow cytometry Annexin V-FITC/PI cell death pathway detection assay}

This assay was performed in order determine if the final PS drug conjugate was capable of enhanced PDT induced cell death, due to its functionalized active 


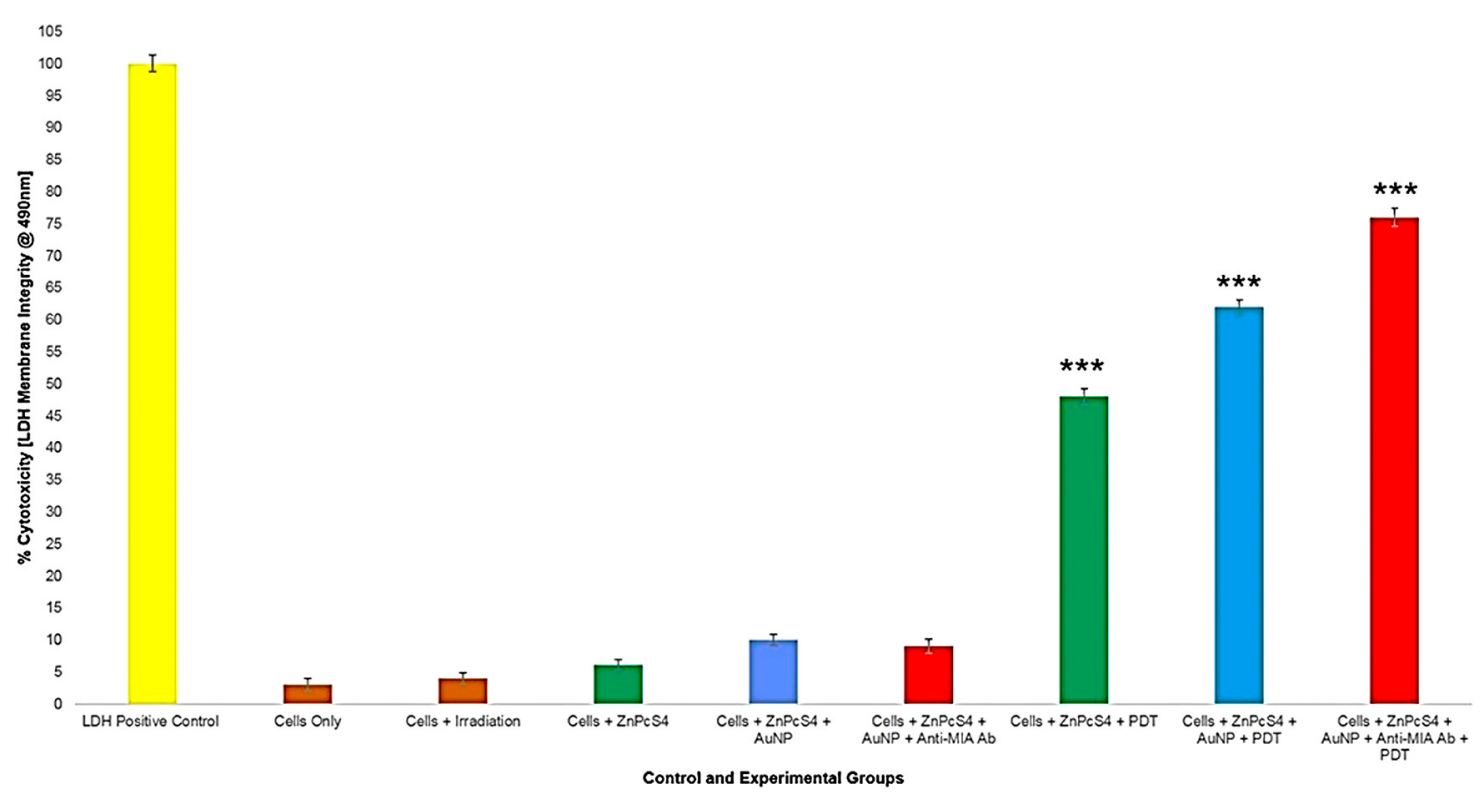

Figure 13: LDH cellular cytotoxicity assay results of control and experimental groups that were subjected to final PS drug conjugate PDT response assays.

Ab targeting abilities and AuNP photothermal promoting nanocarrier, when compared to $\mathrm{ZnPcS}_{4}$ PS drug or AuNPPEG5000-SH-NH 2 administration alone within various control and experimental groups. Flow cytometry scatter grams acquired for the various control and experimental groups were thoroughly analysed, and results have been graphically presented in Figure 14. The control of cells only was used to statistically compare results of viable cells, whereas the necrosis and apoptosis (early and late) controls were used to statistically compare cells undergoing these various modes of cell death. All PDT control and experimental treated groups showed significant modes of cell death when compared to the viable cells only control group, however these significant increases in percentage values varied over the different groups in relation to the mode of cell death each group had undergone.

Within PDT treated control groups which received $2.5 \mu \mathrm{M} \mathrm{ZnPcS}$ PS drug, only $52 \%$ ** of the cells were found viable and the remainder were reported in a $32 \% * *$ early apoptotic and $16 \%$ in a late apoptotic phase of cell death. These results suggest that the administration of $\mathrm{ZnPcS}_{4}$ PS drug only with PDT activation has the ability to induce $48 \%$ apoptotic cell death in MM cells. These results coincide with studies conducted by Robertson et al. (2010) which also reported that PDT laser activated $\mathrm{ZnPcS}_{\text {mix }}$ administered to melanoma skin cancer cells significantly decreased proportion of viable cells, as well as significantly increased the number of cells undergoing early apoptosis [34]. Nevertheless, studies by Noguchi et al. (2015) have stated that cells undergoing early apoptosis modes of cell death, often remain in an autophagy phase and so have the ability to recover [35]. Thus, idealistically, this early mode of apoptotic cell death is not favourable in
PDT cancer treatments, as cells can regenerate themselves and so there is a possibility of cancer re-occurrence.

Whereas, within PDT treated control groups which received $2.5 \mu \mathrm{M} \mathrm{ZnPcS}_{4}-$ AuNP-PEG5000-SH-NH , a more significant increase of $27 \% * * *$ in late apoptosis was noted, with a $40 \% * * *$ in early apoptosis, $5 \% * *$ undergoing necrosis and only $28 \% * *$ of cells being found viable. The improved result of MM cells in late apoptosis when compared to the cells only or PDT treated groups which received $2.5 \mu \mathrm{M} \mathrm{ZnPcS}_{4}$ PS was again attributed to presence of the AuNPs. Studies by El Hussein et al. (2015), support these findings stating that within PDT assays performed on cancer cells, that spherical-oval shaped AuNPs demonstrated the ability to activate a PDT photo thermal apoptotic cell death effects, through notable decreases in cell viability and proliferation, as well as an increase in cytotoxicity [36].

However, the most significant modes of cell death was found within PDT treated experimental groups, which received $2.5 \mu \mathrm{M}$ final PS drug conjugate administration, whereby only $13 \% * * *$ of the cells were found viable, $12 \% * * *$ were undergoing early apoptosis and a staggering $64 \% * * *$ were found in a late apoptotic cell death phase, with a notable $11 \%$ increase in necrotic cells. This highly significant result of MM cells undergoing 65\% late apoptosis, when compared to the control groups of cells only and PDT treated control groups which received 2.5 $\mu \mathrm{M} \mathrm{ZnPcS}$ PS drug only or $2.5 \mu \mathrm{M} \mathrm{ZnPcS}_{4}-\mathrm{AuNP}_{-}$ PEG5000-SH-NH , can be accredited to the fact that $\mathrm{ZnPcS}_{4}$ PS drug was conjugated to Anti-MIA Ab and so actively enhanced PS drug uptake. According to studies by Bazak et al. (2015) significant progress has been made in terms of specific receptor based PS drug molecular targeting of cancer cells though the conjugation of PSs 


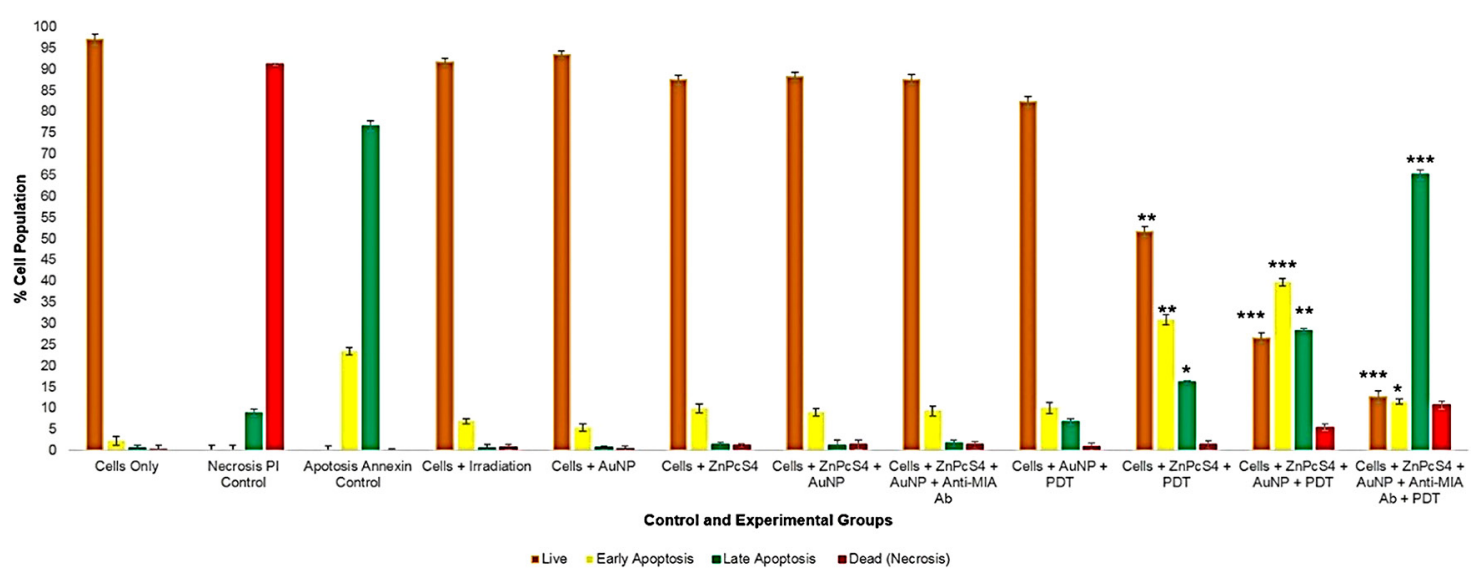

Figure 14: Evaluation of different stages of cell death using flow cytometry Annexin V-FITC/PI staining method on control and experimental groups that were subjected to final PS drug conjugate PDT response assays.

to nano-carriers, which are further functionalized with Ab biomarkers, to improve PS drug active absorption in targeted cells only, leaving healthy surrounding tissues unaffected and overall improving the late apoptotic cell death mode efficacy induction of PDT tumour treatment [37]. Additionally, studies by Pleshkan et al. (2011) indicated that the use of Anti-MIA Ab biomarker conjugated drugs are a promising anti-tumour vehicle for the successful targeted drug delivery and improved treatment of MM [38].

\section{DISCUSSION}

The various molecular characterization assays confirmed that $\mathrm{ZnPcS}_{4}$ PS drug was successfully conjugated onto the surface of AuNPs via ligand absorption and exchange methods. Additionally, these same assays noted effective c' terminus amide bonding of Anti-MIA Abs onto the surface of functionalized amine surface AuNPs, leaving the n' terminus of the Anti$\mathrm{Ab}$ correctly orientated outwards and unobstructed for active tumor biomarker recognition. DLS and ZP results in relation to the final PS drug conjugate noted that the nanoparticle drug system was homogenously pure, monodispersed and moderately stable and so could be considered as an effective PDT PS drug carrier. Moreover, the subcellular localization results reported that the final PS drug conjugate was more efficient at improved $\mathrm{ZnPcS}_{4}$ concentrated cellular absorption within the cytoplasm and nuclei of cells, due to its Anti-MIA Ab biomarker targeting affinity for MM cells.

The findings from this study suggest that the conjugation of Anti-MIA Ab to $\mathrm{ZnPcS}_{4}$ - AuNP-PEG5000$\mathrm{SH}-\mathrm{NH}_{2}$, within the final PS drug conjugate actively and specifically enhanced $\mathrm{ZnPcS}_{4}$ PS drug uptake in MM cells, in comparison to $\mathrm{ZnPcS}_{4}$ PS drug administration alone. Thus, the final PS drug conjugate noted significantly enhanced PDT induced cytotoxic cell death in MM cancer cells, in comparison to control groups. These results were also attributed to the PDT induced photothermal cellular destruction abilities of the AuNPs. Additionally, the majority of MM cells which received the final PS drug conjugate and PDT, were found to be undergoing late apoptotic mode of cell death in comparison to $\mathrm{ZnPcS}_{4}$ PS drug administration alone. Therefore, the results from this study suggest that the $\mathrm{ZnPcS}_{4}$ PS drug delivery within in vitro cultured MM cells can be improved using active nanoparticle biomarker targeting and so the overall outcomes of PDT treatment can be enhanced. Additionally, in relation to the findings from this study, the efficacy of MM treatment could possibly be further upgraded in some groups of clinical patients undergoing immunotherapy by utilizing the same Anti-MIA Ab as a molecular target and observing its treatment outcomes [4].

\section{METHODS}

\section{Chemical synthesis of final conjugate $\mathrm{ZnPcS}_{4}$ - AuNP-PEG5000-SH-NH - Anti-MIA Ab: Conjugation of Anti-MIA Ab to $\mathrm{ZnPcS}_{4}-\mathrm{AuNP}$ - PEG5000-SH-NH}

Working concentration of $0.0005 \mathrm{M} \mathrm{ZnPcS}_{4}$ (Santa Cruz ${ }^{\circledR}$ : sc-264509A) (\%w/v) in 0.001 M Phosphate Buffer Saline (PBS) was prepared and diluted as needed. $1 \mathrm{ml}$ of AuNP-PEG5000-SH-NH 2 (Sigma-Aldrich: 765309) which contained $2.85 \times 10^{15}$ AuNPs per $\mathrm{ml}$ was added to $1 \mathrm{ml}$ of $0.0005 \mathrm{M}$ stock $\mathrm{ZnPcS}_{4}$. It was vortexed at $1500 \mathrm{rpm}$ at room temperature overnight to promote spontaneous ligand exchange (between $\mathrm{Au}$ and PS tetra sulphides) and adsorption (disulphide bond between PEG and PS) (Figure 1). It was purified by micro-centrifugation at 15 $200 \mathrm{rpm}$ for 1 hour. The supernatant was discarded and the pellet which contained the conjugated $\mathrm{ZnPcS}_{4}$ and AuNP-PEG5000-SH-NH ${ }_{2}$ was re-suspended in $1 \mathrm{ml}$ PBS [26, 39].

$200 \mu \mathrm{g} / \mathrm{ml}$ of Anti-MIA Ab (Abcam: 166932) was activated using covalent mode carbodiimide crosslinker 
two-step coupling EDC and NHS chemistry [23, 25, 40, 41]. The activated c' terminus succinimidyl ester on the Anti-MIA Ab reacted was then able to react with the amine group $\left(\mathrm{NH}_{2}\right)$ on the AuNPs, already bound in the $\mathrm{ZnPcS}_{4}$ - AuNP-PEG5000-SH-NH 2 conjugate, and so when mixed together, formed a stable amide bond [39]. This method ensured the correct orientation of the bio-targeting antibody, i. e.: the c' terminus was bound to the amine functionalized AuNPs, while the n' terminus antigenic sites remained free and functional for active targeting (Figure 1). The final PS drug conjugate $\left(\mathrm{ZnPcS}_{4}-\mathrm{AuNP}-\right.$ PEG5000-SH-NH - Anti-MIA Ab) was then subjected to various molecular characterization assays including; UVVisible and FT-IR Spectroscopy, DLS and ZP, as well as immunofluorescent staining subcellular localization and uptake confirmation assays.

\section{Molecular characterization of final conjugate $\mathrm{ZnPcS}_{4}$ - AuNP-PEG5000-SH-NH - Anti- MIA Ab}

\section{UV-Visible spectroscopy}

The UV-Visible absorption and fluorescent spectra of the final conjugate $\mathrm{ZnPcS}_{4}$ - AuNP-PEG5000-SH-NH - Anti-MIA Ab and various controls $\left(\mathrm{ZnPcS}_{4}, \mathrm{AuNP}-\right.$ PEG5000-SH-NH ${ }_{2}$, Anti-MIA Ab, $\mathrm{ZnPcS}_{4}$ - AuNPPEG5000-SH-NH ${ }_{2}$ ) were recorded using a Jenway Genova Nano Plus Life Science Spectrophotometer, to observe binding of the Anti-MIA Ab and $\mathrm{ZnPcS}_{4}$ PS to the surface of the AuNP-PEG5000-SH-NH ${ }_{2}$. The absorption and fluorescent spectra were read using the spectrum/purity scan mode within the 198 - $800 \mathrm{~nm}$ spectral region, as well as read using the $220 \mathrm{~nm}$ protein direct UV option. The Anti-MIA Ab protein and $\mathrm{ZnPcS}_{4}$ PS concentration, as well as number of bound AuNP to the final conjugate was confirmed, after data interpretation [22]. To determine the photostability of the final conjugate the $\mathrm{ZnPcS}_{4}$ AuNP-PEG5000-SH-NH 2 - Anti-MIA Ab Soret and Q bands values were measured prior to laser light irradiation experiments over an 8 week period.

\section{FT-IR Spectroscopy}

FT-IR analysis was performed using the Nicolet iS50 FT-IR Spectrometer (Thermo Scientific) to confirm ligand exchange / absorption (by noting and identifying the formation of strong Au-S and weak di-sulphide bonds), as well as confirm amide bond formation (by noting and identifying the formation of amide bonds). The infrared spectra results were recorded using far infra-red solution software at frequencies ranging from $400-4000 \mathrm{~cm}^{-1}$ with 25 scans.

\section{DLS and ZP}

DLS and ZP measurements were performed using the Malvern Zetasizer Nano ZS (Malvern Instruments, Malvern UK), which has a $4 \mathrm{~mW}$ He-Ne laser of $633 \mathrm{~nm}$ wavelength. Samples were heterogeneous or homogenous $10-50 \mu \mathrm{g} / \mathrm{ml}$ diluted suspensions in water and were analyzed at $25^{\circ} \mathrm{C}$, using a $13^{\circ}$ and $173^{\circ}$ angel.

\section{Subcellular localization}

Culture plates were seeded at $2.5 \times 10^{5}$ cells/ ml with A375 MM cells, which had sterile coverslips inserted into them and incubated at $37^{\circ} \mathrm{C}$ for 4 hours, to allow for cellular attachment. After 4 hours of incubation, the growth media was discarded and replaced with fresh growth media which contained a pre-determined dose response of $2.5 \mu \mathrm{M}$ PS alone or the final PS drug conjugate to make up a final volume of $3 \mathrm{ml}$.

The plates were incubated at $37^{\circ} \mathrm{C}$ for an additional 20 hours in the dark. After incubation, the primary $\mathrm{Ab}$ [200 $\mu \mathrm{g} / \mathrm{ml}$ ICAM-1 Mouse Monoclonal IgG1 Ab diluted in $0.01 \mathrm{M}$ PBS in $1 \%(\mathrm{w} / \mathrm{v}) \mathrm{BSA}$ and $0.01 \%(\mathrm{w} / \mathrm{v})$ sodium azide buffer solution, in a ratio 1:200] was added followed by the secondary Ab $[200 \mu \mathrm{g} / \mathrm{ml} 0.5 \mathrm{ml}$ Goat Anti-Mouse IgG-FITC human absorbed, fluorescein conjugated antibody, diluted in $0.01 \mathrm{M}$ PBS in $1 \%(\mathrm{w} / \mathrm{v}) \mathrm{BSA}$ and $0.01 \%(\mathrm{w} / \mathrm{v})$ sodium azide buffer solution in a ratio $1: 200]$ and then the cells were permanently fixed onto their coverslips. The coverslips were then stained with $50 \mu \mathrm{l}$ of $1 \mu \mathrm{g} / \mathrm{ml} \mathrm{40-6-Diamidino-2-phenylindole} \mathrm{(DAPI)} \mathrm{and}$ inverted onto glass microscope slides and sealed with nail varnish. The slides were examined using the filter fluorescent settings of a Carl Zeiss Axio Z1 Observer immuno fluorescent microscope. The 358Ex / 461Em filter was used to detect blue DAPI counter stained nuclei in cultured cells, while the 495Ex / 519Em filter was used to detect any green FITC stained ICAM-1 membrane proteins and the $589 \mathrm{Ex} / 610 \mathrm{Em}$ filter was used to detect any $\mathrm{Cy} 5$ red auto fluorescent signal that was produced from the $\mathrm{ZnPcS}_{4}$.

\section{Cell culture and preparation of cell culture plates}

Commercially purchased Human malignant melanoma cell line A375 (MM) were obtained from the European Collection of Authenticated Cell Cultures (ECACC no: 88113005) and cultured in a $175 \mathrm{~cm}^{2}$ cell culture flask, which contained Dulbecco's Modified Eagle's medium (DMEM) basal medium supplemented with $15 \%(\mathrm{v} / \mathrm{v})$ Foetal Bovine Serum (FBS), $0.1 \%(\mathrm{v} / \mathrm{v})$ Amphotericin- $\beta$ and $0.1 \%$ (v/v) Penicillin-Streptomycin. The cultured cells were incubated at $37{ }^{\circ} \mathrm{C}$, with $5 \% \mathrm{CO}_{2}$ tension and $85 \%$ humidity.

Once confluent monolayers of cultured cells were obtained, they were detached using Tryple TMSelect. The cellular suspensions were then pelleted out and resuspended in complete cell growth medium. These cellular suspensions were then sub-cultured into $3.4 \mathrm{~cm}$ diameter cell culture plates at a seeding ratio of $2.5 \times 10^{5} \mathrm{cells} / \mathrm{ml}$, which contained $3 \mathrm{ml}$ of complete cell growth medium. 
The culture plates were then incubated for 4 hours to allow for cellular attachment.

This particular cell line was purchased from ECACC in March 2018 and was passaged within these laboratory experiments for fewer than 6 months after receipt and so re-authentication was not required. However, the ECACC cell bank notes that they utilize human cell lines Short tandem repeat (STR) loci human cell line profiling methods of characterization to ensure cell line authenticity.

\section{PDT laser parameters, PS drug addition to culture plates and laser irradiation}

After 4 hours incubation, culture plates were divided into various control and experimental groups, for $\mathrm{ZnPcS}_{4}$ PDT PS dose response or final PDT PS drug conjugate assays. Then the cell culture media was freshly replaced. The groups which required PS or final PS drug conjugate, had the required concentration added to their culture media and were incubated for an additional 20 hours. Then the groups which required laser treatment (wavelength: $673 \mathrm{~nm}$ and fluency:10 J/ $\mathrm{cm}^{2}$ ) were irradiated for approximately 16 minutes and 8 seconds in $1 \mathrm{ml} 0.001$ M PBS using a Roithner $1000 \mathrm{~mA} 673 \mathrm{~nm}$ high power semiconductor diode laser (Arroyo 4210). The culture media of all plates was then freshly replaced, and plates were incubated for an additional 24 hours.

\section{$\mathrm{ZnPcS}_{4}$ PS PDT dose response assays}

To determine the $\mathrm{IC}_{50}$ of PS PDT treatment alone a concentration range between $0.25-10 \mu \mathrm{M}$ of $\mathrm{ZnPcS}_{4}$ was administered to various control and experimental culture plate groups, as discussed above. Post laser irradiation (for some groups) and after an additional 24 hours of incubation, following detachment and cellular suspension these groups were subjected to Trypan blue and cytotoxicity analysis. Note: the $\mathrm{IC}_{50}$ of $\mathrm{ZnPcS}_{4}$ was found to be $2.5 \mu \mathrm{M}$.

\section{$\mathrm{ZnPcS}_{4}$ - AuNP-PEG5000-SH-NH - Anti-MIA Ab final PS drug conjugate PDT response assays}

Thus, to determine if the final PS drug conjugate enhanced PDT treatment in comparison to PS PDT treatment alone, $2.5 \mu \mathrm{M}$ of the final PS drug conjugate and/or laser light irradiation was administered to various control and experimental culture plate groups, as discussed above. Post laser irradiation (for some groups) and after an additional 24 hours of incubation, following detachment and cellular suspension these groups were subjected to various biochemical assays.

\section{Biochemical assays}

\section{Morphology}

Post-PDT treatment, the effect on cellular morphology was viewed by light microscopy and observed at $400 \times$ magnification using an inverted microscope
(Olympus CKX41) that had a digital camera (Olympus C5060-ADUS) attached to it.

\section{The trypan blue exclusion test}

10 ul of $0.4 \%(w / v)$ Trypan Blue stain was mixed with $10 \mu \mathrm{l}$ of cellular suspensions and loaded onto a disposable Countess ${ }^{\circledR}$ cell counting chamber slide. The number of viable cells per ml was quantified using an Invitrogen Countess ${ }^{\circledR}$ II FL Automated Cell Counter.

\section{LDH cellular cytotoxicity and membrane integrity assay}

The CytoTox96® Non-Radioactive Cytotoxicity Assay (Promega, G1780), measures the amount of lactate dehydrogenase $(\mathrm{LDH})$ that is released into culture medium upon cell lysis and so can be used to determine cellular cytotoxicity. Thus, following manufacturer's instructions, $50 \mu \mathrm{l}$ of complete cell culture media from each experimental and control culture plate was removed and added to $50 \mu \mathrm{l}$ of LDH Reconstituted Substrate Mix in a flat 96 well clear bottom plate. LDH absorbance was recorded at $490 \mathrm{~nm}$ using a spectrophotometer (Perkin Elmer, Victor ${ }^{3}$, 1420 Multilabel Counter) and so used to calculate cellular lysis and cytotoxicity.

\section{Flow cytometry Annexin V-FITC/PI cell death pathway detection assay}

Following manufacturer's instructions, the Annexin V-FITC/PI cell death detection kit (BD Scientific: $\mathrm{BD} / 556570$ ), was used to detect early or late apoptotic, as well as necrotic phases of cells death in various control and experimental groups, using the BD Accuri ${ }^{\mathrm{TM}} \mathrm{C} 6$ flow cytometer.

\section{Statistical analysis}

Graphs represent the mean and the standard deviation of biochemical assays done in duplicate for six independent experiments. The Students t-test and oneway analysis of variances (ANOVA), was used for normal distributed data, whereas the Mann-Whitney test was used for non-normal distributed data. These tests were used to determine the significance difference between control and experimental groups where values in the $95 \%$ confidence interval $\left(\mathrm{P}<0.05^{*}, \mathrm{P}<0.01 * *\right.$ or $\left.\mathrm{P}<0.001 * * *\right)$ were accepted as statistically different.

\section{Abbreviations}

MM: Metastatic melanoma; PDT: photodynamic therapy; PS: photosensitizer; nm: nanometre; ROS: reactive oxygen species; $\mathrm{ZnPcS} / \mathrm{ZnPcS}_{\text {mix }}$ : zinc sulpho phthalocyanine; AuNP: gold nanoparticle; MIA: Melanoma Inhibitory Activity; Ab: Antibody; AntiMIA: Anti-Melanoma Inhibitory Activity; $\mathrm{ZnPcS}_{4}$ : Zinc phthalocyanine tetra-sulphonic acid; AuNP-

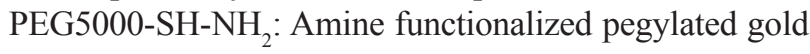


nanoparticle; UV: Ultra Violet; $\mu \mathrm{M}$ : Micromolar; PEG: Polyethylene glycol; C: Carbon; S: Sulphur; H: Hydrogen; $\mathrm{N}$ : Nitrogen; $\mathrm{NH}_{2}$ : Anime; ml: millilitre; $\mu \mathrm{g}$ : Microgram; O: Oxygen; n': terminus Amino terminus; c': terminus Carboxyl terminus; FT-IR: Fourier Transform Infrared; Au: Gold; DLS: Dynamic Light Scattering; ZP: Zeta Potential; PDI: Polydispersity Index; $\mathrm{mV}$ : millivolt; $\mathrm{IC}_{50}$ : Inhibitory Concentration of $50 \% ; \mathrm{J} / \mathrm{cm}^{2}$ : Joules per $\mathrm{cm}^{2}$; LDH: Lactate Dehydrogenase; FTIC: Fluorescein isothiocyanate; PI: Propidium iodide; M: Molar; PBS: Phosphate Buffered Saline; rpm: rotation per minute; mg: milligrams; EDC: 1-Ethyl-3-(3-dimethylaminopropyl) carbodiimide; NHS: N-Hydroxysuccinimide; $\mu \mathrm{l}$ : Microliter; ${ }^{\circ} \mathrm{C}$ : Degree Celsius; mW: milliwatt; He-Ne: Helium-neon; ICAM-1: Intercellular adhesion molecule1; BSA: Bovine serum albumin; DAPI: 4',6-diamidino2-phenylindole; ECACC: European Collection of Authenticated Cell Cultures; DMEM: Dulbecco's Modified Eagle's medium; FBS: Foetal Bovine Serum; $\mathrm{CO}_{2}$ : Carbon dioxide; mA: milliampere; $\mathrm{BD}$ : Becton Dickinson; ANOVA: Analysis of variances.

\section{Author contributions}

Ms. C. Naidoo contributed to the study design, acquisition of data, analysis and interpretation of data, drafting of article. Dr. C.A. Kruger contributed to the concept and design of the study, analysis and interpretation of data, revision of article for important content. Prof. H. Abrahamse contributed to the revision of article and final approval of article.

\section{CONFLICTS OF INTEREST}

This manuscript is based on our original research and has neither been published, nor is being considered elsewhere for publication. Additionally, all the authors note that they do not have any relationships that they believe could be construed as a conflict of interest with regards to manuscript review process.

\section{FUNDING}

This work is based on the research supported by the South African Research Chairs Initiative of the Department of Science and Technology and National Research Foundation of South Africa (Grant No 98337). The authors sincerely thank the University of Johannesburg, the National Laser Centre and the National Research Foundation - South African Research Chairs Initiative (NRF-SARChI) for their financial grant support.

\section{REFERENCES}

1. Wang XL, Wang HW, Guo MX, Xu SZ. Treatment of skin cancer and pre-cancer using topical ALA-PDT - a single hospital experience. Photodiagnosis Photodyn Ther. 2008;
5: 127-133. https://doi.org/10.1016/j.pdpdt.2008.05.003. [PubMed].

2. Swavey S, Tran M. Porphyrin and Phthalocyanine Photosensitizers as PDT agents: A new modality for the treatment of melanoma. InTech Open. 2013. https://doi. org/10.5772/54940.

3. Naidoo C, Kruger CA, Abrahamse H. Photodynamic Therapy for Metastatic Melanoma Treatment: A Review. Technol Cancer Res Treat. 2018; 17: 1533033818791795. https://doi.org/10.1177/1533033818791795. [PubMed].

4. Lugowska I, Teterycz P, Rutkowski P. Immunotherapy of melanoma. Contemp Oncol (Pozn). 2018; 22: 61-67. https://doi.org/10.5114/wo.2018.73889. [PubMed].

5. Tang T, Yong-hui L, Guo-Sheng T, Xiao-Ming W, Gui-Hua L, Yong-Hua Y. Targeted photosensitizer nanoconjugates based on human serum albumin selectively kill tumour cells upon photo-irradiation. RSC Advances. 2015; 5: 5057250579. https://doi.org/10.1039/C5RA05251C.

6. Mokwena MG, Kruger CA, Tynga IM, Abrahamse H. A review of nanoparticle photosensitizer drug delivery uptake systems for photodynamic treatment of lung cancer. Photodiagnosis Photodyn Ther. 2018; 22: 147-154. https:// doi.org/10.1016/j.pdpdt.2018.03.006. [PubMed].

7. Kruger CA, Abrahamse H. Utilisation of Targeted Nanoparticle Photosensitiser Drug Delivery Systems for the Enhancement of Photodynamic Therapy. Molecules. Molecules. 2018; 23: 2628. https://doi.org/10.3390/ molecules23102628. [PubMed].

8. Zhang Y, Lovell JF. Recent applications of phthalocyanines and naphthalocyanines for imaging and therapy. Wiley Interdiscip Rev Nanomed Nanobiotechnol. 2016; 9: e1420. https://doi.org/10.1002/wnan.1420. [PubMed].

9. Kataoka H, Nishie H, Hayashi N, Tanaka M, Nomoto A, Yano S, Joh T. New photodynamic therapy with nextgeneration photosensitizers. Ann Transl Med. 2017; 5: 183. https://doi.org/10.21037/atm.2017.03.59. [PubMed].

10. Chen S, Hao X, Liang X, Zhang Q, Zhang C, Zhou G, Shen S, Jia G, Zhang J. Inorganic nanomaterials as carriers for drug delivery. J Biomed Nanotechnol. 2016; 12: 1-27. https://doi.org/10.1166/ibn.2016.2122. [PubMed].

11. Liu W, Kelly JW, Trivett M, Murray WK, Dowling JP, Wolfe R, Mason G, Magee J, Angel C, Dobrovic A, McArthur GA. Distinct clinical and pathological features are associated with the BRAFT1799A (V600E) mutation in primary melanoma. J Invest Dermatol. 2007; 127: 900905. https://doi.org/10.1038/sj.jid.5700632. [PubMed].

12. Conde J, Doria G, Baptista M. Noble metal nanoparticles applications in cancer. Journal of Drug Delivery. 2012; 2012. https://doi.org/10.1155/2012/751075.

13. Bosserhoff AK, Buettner R. Expression, function and clinical relevance of MIA (melanoma inhibitory activity). Histol Histopathol. 2002 .17: 289-300. https://doi. org/10.14670/HH-17.289. [PubMed] 
14. Hudlikar MS, Li X, Gagarinov IA, Kolishetti N, Wolfert MA, Boons GJ. Controlled Multi-functionalization Facilitates Targeted Delivery of Nanoparticles to Cancer Cells. Chemistry. 2015; 22: 1415-1423. https://doi. org/10.1002/chem.201503999. [PubMed].

15. Moghimi SM, Hunter AC, Murray JC. Long-circulating and target-specific nanoparticles: theory to practice. Pharmacol Rev. 2001; 53:283-318.[PubMed]

16. Smith BA, Xiao S, Wolter W, Wheeler J, Suckow MA, Smith BD. In vivo targeting of cell death using a synthetic fluorescent molecular probe. Apoptosis. 2011; 16: 722-731. https://doi.org/10.1007/s10495-011-0601-5. [PubMed].

17. Haley B, Frenkel E. Nanoparticles for drug delivery in cancer treatment. Urol Oncol. 2008; 26: 57-64. https://doi. org/10.1016/j.urolonc.2007.03.015. [PubMed].

18. Kemp JA, Shim MS, Heo CY, Kwon YJ. "Combo" nanomedicine: co-delivery of multi-modal therapeutics for efficient, targeted, and safe cancer therapy. Adv Drug Deliv Rev. 2016; 98: 3-18. https://doi.org/10.1016/j. addr.2015.10.019. [PubMed].

19. Borgatti-Jeffreys A, Hooser SB, Miller MA, Lucroy MD. Phase I clinical trial of the use of zinc phthalocyanine tetrasulfonate as a photosensitizer for photodynamic therapy in dogs. Am J Vet Res. 2007; 68: 399-404. https://doi. org/10.2460/ajvr.68.4.399. [PubMed].

20. Kuzyniak W, Schmidt J, Glac W, Berkholz J, Steinemann G, Hoffmann B, Ermilov EA, Gürek AG, Ahsen V, Nitzsche B, Höpfner M. Novel zinc phthalocyanine as a promising photosensitizer for photodynamic treatment of esophageal cancer. Int J Oncol. 2017; 50: 953-963. https://doi. org/10.3892/ijo.2017.3854. [PubMed].

21. Abramczyk H, Brozek-Pluska B, Surmacki J, Musial J, Kordek R. Oncologic photodynamic diagnosis and therapy: confocal Raman/fluorescence imaging of metal phthalocyanines in human breast cancer tissue in vitro. Analyst. 2014; 139: 5547-5559. https://doi.org/10.1039/ C4AN00966E. [PubMed].

22. Tan G, Kantner K, Zhang Q, Soliman MG, del Pino P, Parak WJ, Onur MA, Valdeperez D, Rejman J, Pelaz B. Conjugation of polymer-coated gold nanoparticles with antibodies - Synthesis and characterization. Nanomaterials (Basel). 2015; 5: 1297-1316. https://doi.org/10.3390/ nano5031297. [PubMed].

23. Decker R, Oldenburg SJ. Nanomaterial Bioconjugation Techniques: The future of bioimaging, optical imaging Method: Covalent Bioconjugation of Antibodies to Carboxyl Terminated Nanoparticles. Merck. 2017 ; 37-39.

24. Kuipers BJH, Gruppen H. Prediction of Molar Extinction Coefficients of Proteins and Peptides Using UV Absorption of the Constituent Amino Acids at $214 \mathrm{~nm}$ To Enable Quantitative Reverse Phase High-Performance Liquid Chromatography-Mass Spectrometry Analysis. J Agric Food Chem. 2007; 55: 5445-5451. https://doi.org/10.1021/ jf0703371. [PubMed].
25. Stuchinskaya T, Moreno M, Cook MJ, Edwards DR, Russell DA. Targeted photodynamic therapy of breast cancer cells using antibody-phthalocyanine-gold nanoparticle conjugates. Photochem Photobiol Sci. 2011; 10: 822-831. https://doi.org/10.1039/c1pp05014a. [PubMed].

26. Siriwardana K, Gadogbe M, Ansar SM, Vasquez ES, Collier WE, Zou S, Walters KB, Zhang D. Ligand Adsorption and Exchange on Pegylated Gold Nanoparticles. J Phys Chem C. 2014; 118: 11111-11119. https://pubs.acs.org/ doi/10.1021/jp501391x.

27. Sakamoto K, Ohno-Okumura E. Syntheses and Functional Properties of Phthalocyanines. Materials 2009, 2, 11271179; https://doi:10.3390/ma2031127.[PubMed]

28. Nguyen KC. Quantitative analysis of $\mathrm{COOH}-$ terminated alkanethiol SAMs on gold nanoparticle surfaces. Advances in Natural Sciences: Nanoscience and Nanotechnology. 2012; 3: 045008. https://doi. org/10.1088/2043-6262/3/4/045008.

29. Mecozzi M, Sturchio E. Computer Assisted Examination of Infrared and Near Infrared Spectra to Assess Structural and Molecular Changes in Biological Samples Exposed to Pollutants: A Case of Study. J Imaging. 2017; 3: 11. https:// www.mdpi.com/2313-433X/3/1/11.

30. Yu X, Trase I, Ren M, Duval K, Guo X, Chen Z. Design of nanoparticle-based carriers for targeted drug delivery. Journal of Nanomaterials. 2016; 2016. http://dx.doi. org/10.1155/2016/1087250. [PubMed].

31. Wu B, Zhao N. A targeted nanoprobe based on carbon nanotubes-natural biopolymer chitosan composites. Nanomaterials (Basel). 2016; 6: 216. https://doi. org/10.3390/nano6110216. [PubMed].

32. Hong EJ, Choi DG, Shim MS. Targeted and effective photodynamic therapy for cancer using functionalized nanomaterials. Acta Pharm Sin B. 2016; 6: 297-307. https:// doi.org/10.1016/j.apsb.2016.01.007. [PubMed].

33. Liu Y, Ma W, Wang J. Theranostics of Gold Nanoparticles with an Emphasis on Photoacoustic Imaging and Photothermal Therapy. Curr Pharm Des. 2018; 24: 2719-2728. https://doi. org/10.2174/1381612824666180604112201. [PubMed].

34. Robertson CA, Evans D, Abrahamse H. The In vitro PDT efficacy of a novel Metallophthalocyanine (MPc) derivative and established 5-ALA photosensitizing dyes against human metastatic melanoma cells. Lasers Surg Med. 2011; 42: 926-936. https://doi.org/10.1002/1sm.20980. [PubMed].

35. Noguchi M, Hirata N, Edamura T, Ishigaki S, Suizu F. Intersection of apoptosis and autophagy cell death pathways. J Mol Cell Biol. 2015; 2: 1004.

36. El-Hussein A, Mfouo-Tynga I, Abdel-Harith M, Abrahamse H. Comparative study between the photodynamic ability of gold and silver nanoparticles in mediating cell death in breast and lung cancer cell lines. J Photochem Photobiol B. 2015; 153: 67-75. https://doi.org/10.1016/j. jphotobiol.2015.08.028. [PubMed]. 
37. Bazak R, Houri M, El Achy S, Kamel S, Refaat T. Cancer active targeting by nanoparticles: a comprehensive review of literature. J Cancer Res Clin Oncol. 2014; 141: 769-784. https://doi.org/10.1007/s00432-014-1767-3. [PubMed].

38. Pleshkan VV, Zinovyeva MV, Sverdlov E. Melanoma: Surface markers as the first point of targeted delivery of therapeutic genes in multilevel gene therapy. Mol Biol (Mosk). 2011; 45: 375-433. https://doi.org/10.1134/ S0026893311030149.

39. Woehrle GH, Brown LO, Hutchison JE. Thiolfunctionalized, 1.5-nm gold nanoparticles through ligand exchange reactions: Scope and mechanism of ligand exchange. J Am Chem Soc. 2005; 127: 2172-2183. https:// doi.org/10.1021/ja0457718. [PubMed].

40. Vashist SK. Comparison of 1-Ethyl-3-(3Dimethylaminopropyl) Carbodiimide Based Strategies to Crosslink Antibodies on Amine-Functionalized Platforms for Immunodiagnostic Applications. Diagnostics (Basel). 2012; 2: 23-33. https://doi.org/10.3390/ diagnostics2030023. [PubMed].

41. Jazayeri MH, Amani H, Pourfatollah AA, Pazoki-Toroudi $\mathrm{H}$, Sedighimoghaddamf B. Various methods of gold nanoparticles (GNPs) conjugation to antibodies. Sensing and Bio-Sensing Research. 2016; 9: 17-22. https://doi. org/10.1016/j.sbsr.2016.04.002. 